\title{
The Effect of the Cash Conversion Cycle on the Z-scores of Fresh Milk Companies in Greece
}

Sophia Nema*, Katerina Lyroudi**

\section{Abstract}

The dairy products sector in Greece is very important for the Greek economy because it is associated to the primary sector and also has a strong exportation orientation. The impact of the financial crisis was evident in the dairy industry also along with the other sectors of the economy. The objective of this study is to examine the effect of the Cash Conversion Cycle as measure of liquidity, on the Z-scores of three selected fresh milk firms in Greece. We examine the market leader fresh milk company "DELTA", in comparison to a new (2011) innovative firm regarding its distribution channel "THESS GALA PIES", founded in Larissa, and to another similar sized and locality to the latter firm "TRIKKI" as representatives of the whole fresh milk/dairy products industry. On all three companies two Altman solvency prediction models are used: (a) the Altman $Z^{\prime}$-score (1983) model revised for non - publicly traded firms, and (b) the Altman Z"-score (2000) model for firms operating in emerging markets. The regression analysis of the effect of the Cash Conversion Cycle on the Z-scores of both models for all entities showed that the two aforementioned sets of data are highly associated but the hypothesis of a linear relationship between them was rejected.
Keywords: Solvency prediction models, Cash Conversion Cycle, Z-score, Greek dairy industry

JEL Code: G33, M40

A first draft of this paper was presented at the $8^{\text {th }}$ National Conference of the Financial Engineering and Banking Society (FEBS), Athens, 18-19 December 2018.

\section{INTRODUCTION}

The dairy products sector in Greece is comprised of a large number of companies which present a considerable variability in sales, assets, market intrusion according to Stamatelos (2016). Only two firms of the dairy industry sector, EVROFARMA and KRIKRI, are traded on the Athens Stock Exchange, while large companies in the sector, such as DELTA, have been withdrawn from the Athens Stock Exchange since 2010. A huge number of small to medium sized firms fill the gaps in the local markets whilst Eurostat data shows that between 2003 and 2015 more than $90 \%$ of the firms operating in the sector produce less than 5,000 tons of milk per year. Based on the information from the annual reports of IOBE (Institute of Economic and Industrial Research) for the years 2014 to 2018 Figure 1 depicts the dynamics of the dairy industry in Greece.

\footnotetext{
* Sophia Nema, Dipl. Civil Engineer AUTh, MBA, MSc, MA, Hellenic Open University 2018 MBA Graduate, Address for correspondence: 13, G. Averophe Street, P.C. 41222, Larissa, Greece

* Contact author: Katerina Lyroudi, PhD, Adjunct Assistant Professor (SEP), Hellenic Open University, Voulgaroktonou 13 street, 58100 Giannitsa, Greece
} 
Figure 1: The Dynamics of the Dairy Industry in Greece

\begin{tabular}{|l|l|l|l|l|l|}
\hline Variables & $\mathbf{2 0 1 4}$ & $\mathbf{2 0 1 5}$ & $\mathbf{2 0 1 6}$ & $\mathbf{2 0 1 7}$ & $\mathbf{2 0 1 8}$ \\
\hline Number of Employees in the Dairy Industry & 8807.9 & 10041 & 11705 & 15136 & 16073 \\
\hline Greek Unemployment Rate in general & $26.5 \%$ & $24.9 \%$ & $23.6 \%$ & $23.3 \%$ & $21.2 \%$ \\
\hline $\begin{array}{l}\text { Trade Balance of the Dairy Industry in millions of } \\
\text { euros }\end{array}$ & -358.7 & -178.4 & -142.2 & -200.2 & NA \\
\hline $\begin{array}{l}\text { Earnings before Interest and Taxes (EBIT) of the } \\
\text { Dairy Industry in millions of euros }\end{array}$ & 5.7 & 18.1 & 29.1 & 72 & NA \\
\hline $\begin{array}{l}\text { Earnings after Taxes (EAT) of the Dairy Industry in } \\
\text { millions of euros }\end{array}$ & -4.9 & 7.0 & 16.3 & 54.5 & NA \\
\hline
\end{tabular}

Source: IOBE annual reports Food and Beverages: Facts and Figures 2014 to 2018.

Arvanitidou and Anastasiadou (2015) indicated that the dairy products sector presents low elasticity in terms of price and income as dairy products are essential for a balanced nutritional diet. During the economic recession period the fresh milk market was suffering reduction in sales, whilst the allocation to primary production associated with the collection and transportation of the raw material entails high production cost, which is increased due to the short duration of the milk life-cycle.

Due to previously heavy lending and the pressure put in the dairy products sector following the economic recession, the firms of the industry chose to proceed to mergers and acquisitions [Kelenidou (2015), Manifava (2017) and BusinessNews (2018)].

The wider dairy industry has been affected over time by the economic downturn in recent years, with domestic consumption posting a downward trend after 2009, in the various market categories such as fresh milk, high pasteurization milk, yoghurt, dairy products. Following the imposition of capital controls in the summer of 2015 , the rate of decline has increased, due to the greater burden on consumers due to direct and indirect taxes, resulting in a gradual contraction of their purchasing power. In particular, in the summer of 2015 , the transfer of many food products from the low VAT rate of $13 \%$ to $23 \%$ and then a second increase to $24 \%$ from June $1^{\text {st }}, 2016$ caused a further decline in demand even for basic fast-moving goods, such as dairy products. The immediate consequence of the worsening of the economic climate was the significant volume and value losses observed up to the current period in milk and yoghurt, while the dairy market clearly showed a milder downturn. Specifically, according to IRI GREECE (Information Resources Incorporated), an international market research company based in the US, the total volume of all categories of milk handled in 2016 decreased by $12.3 \%$ to 329,978 tons, which was translated into a decline in consumption of about 46,300 tons.

According to Nikolaidis (2017), the Marinopoulos super market chain dysfunction, before finalizing its acquisition by Sklavenitis, can be considered as a parameter that adversely affected the market for pasteurized and high pasteurization milk, in addition to the deterioration in economic conditions. It is recalled that the former applied an aggressive commercial policy by offering 99 cents a liter in all brands every Monday and Tuesday, allowing it to accrue $65 \%$ of the milk sales in the super market.

The impact of the financial crisis was evident in the dairy industry. Decreasing consumption has led the dairy firms in the sector to reduce their daily milk volumes, whilst others have stopped working with livestock units, with several of the latter ones closing down. At the same time, the dairy firms passed on to the 


\section{Articles}

farmers a considerable part of the cost by delaying payments due to liquidity problems and by pushing down on delivery prices, as they were under pressure by super markets for cheaper products. In the current period, milk prices at European level have increased; with the increase being a negative parameter for the industries, given the large drop in consumption. According to market estimates, at the end of February 2017, the average price of good quality cow's milk was set at $0.40 €$ from $0.35 €$ in the previous year.

Moreover, the release of milk life in 2014 has allowed domestic dairies to reduce the cost of refunds, which eventually burdens retail prices. However, supermarket chains and large vendors now have the option of importing cheaper milk from foreign industries which they promote to the domestic market as fresh, under the condition it had previously been pasteurized, at competitive prices either as a branded product or as a private label product. This fact will increase competition between domestic dairy industries and retailers, even in the case that the first ones proceed to imports from abroad, as it is quite likely that part of their market shares will be lost according to Nikolaidis (2017).

The aforementioned event has already a negative impact on the Greek economy as it can be seen from Figure 1, whereby the trade balance of the dairy industry in Greece was $-142,2$ million euros in 2016 and reached $-200,2$ million euros in 2017. According to a sectoral study based on 80 firms of Infobank Hellastat (2017) and its chairman Mr. Guzelo Nikolas, the claims over the last 3 years in the dairy industry are collected over a period of 4 months. The sales of milk in the supermarkets were reduced by $4.7 \%$ in 2017 . Regarding the period 2013 to 2017 the reduction was $27 \%$.

The importance of the dairy industry is crucial to the Greek economy as it supports the livestock raising activity at the local level. However, the survival of the fresh milk industry depends heavily on the unfavorable economic environment of the recent years' economic recession, which led to lack of liquidity in the Greek Market, causing delays in payments, increased cost of capital and a vicious cycle that fed the recession. This cycle has to be broken by the policy makers to free the milk/dairy products market in particular and the Greek market in general from the reasons that cause more recession instead of development and growth.

Hence, focusing on liquidity as a major factor first of a firm's survival and second of its growth, the objective of this study is to investigate the effect of the Cash Conversion Cycle (CCC) as a dynamic measure of liquidity on the Z-scores of three selected fresh milk companies assessing their survival ability. We examine the market leader, fresh milk company "DELTA", in comparison to a new (founded in 2011 in Thessaly) innovative firm regarding its distribution channel "THESS GALA PIES", founded in Larissa, and to another similar sized and locality to the latter firm, "TRIKKI" but traditional in all its sectors as all the other firms of that industry, as representatives of the whole fresh milk/dairy products industry in Greece. By selecting these particular three firms, we will be able to see whether the size or the distribution channels used matters in the firm's viability as a first glance. The relation of the cash conversion cycle and the firm's viability measured by the Z-score has not been examined so far to our knowledge. Our study is original in this respect and enriches the literature on the issue of the cash conversion cycle and a firm's viability. This study is useful and will be a contribution to the academincias enriching the pertinent literature and also to practitioners and policy makers. It will give the latter insights regarding the effect of reduced liquidity to the financial viability of firms in the specific industry sector, so that they can take the proper precautionary 


\section{Articles}

measures and organize the sector better. Future research could extend the present and investigate in depth the factors that affect the firm's viability of the dairy products sector in terms of other liquidity measures (the static ones), management efficiency, marketing efficiency, locality, size , etc.
The Effect of the Cash Conversion Cycle on the Z-scores of Fresh Milk Companies in Greece

Picture 1 shows a "station" of the way milk is distributed by the company "THESS GALA PIES", through vending machines that sell fresh milk being poured into bottles (glass or plastic) for the customers.

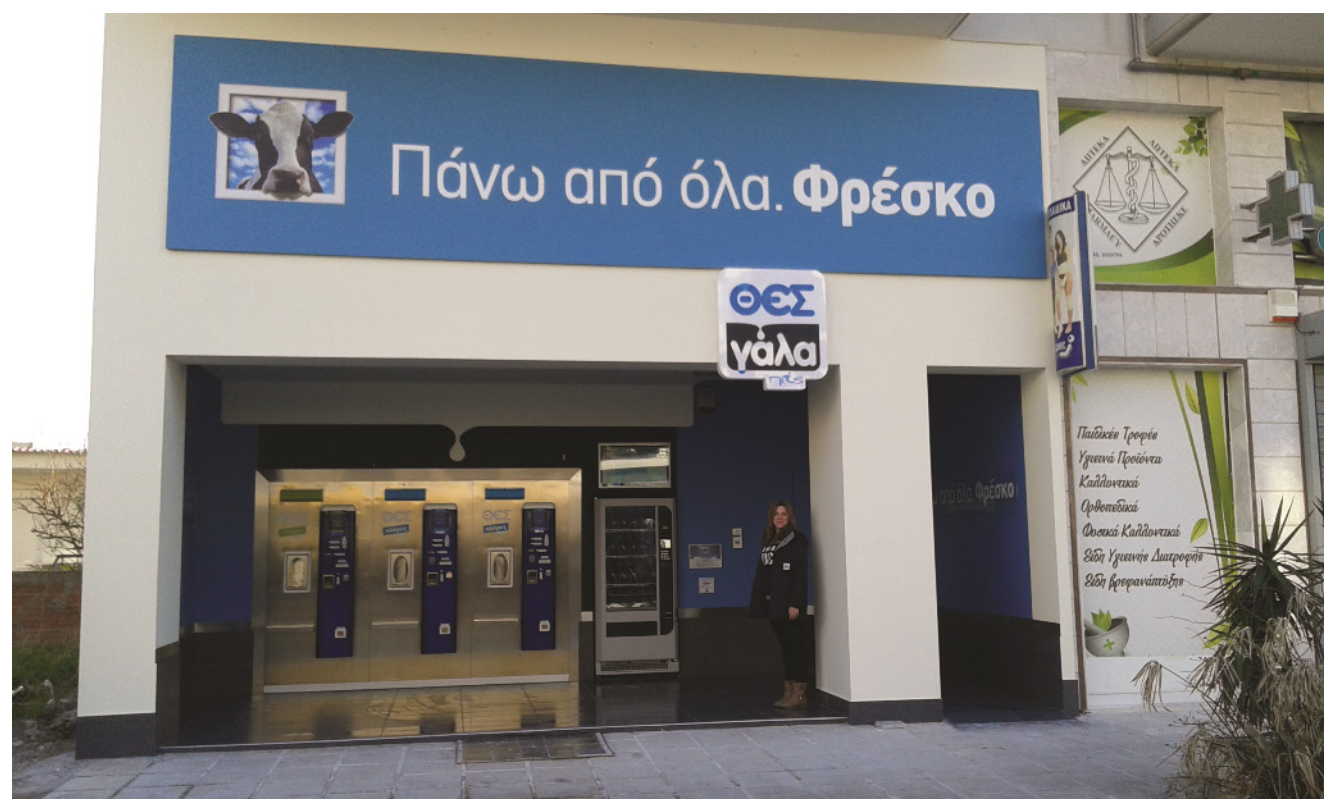

Picture 1: A station of fresh milk vending machines of "THESS GALA PIES",

In order to achieve our objective, the paper is organized as follows: The next section contains a two parts review of literature, one for the Altman's Z-score and one for the cash conversion cycle. Section 3 presents the methodology. Section 4 shows the data used and the sources. Section 5 depicts and discusses the results and section 6 contains a summary and concluding remarks.

\section{LITERATURE REVIEW}

\subsection{The original and revised Altman's Z-score models and their application as a performance rating and solvency prediction tool}

Altman (1968) developed a multivariate model using discriminant analysis techniques in order to predict bankruptcy of financially distressed companies using a series of financial ratios. Altman's point of view was that the traditional financial ratios analysis was providing an indication in terms of a company's bankruptcy probability and did not contain a prediction, as the analysis was univariate. Hence, Altman (1968) investigated the contribution and statistical importance of financial ratios for two groups of companies; one consisting of bankrupt companies and the other of non-bankrupt ones (Altman, 1968).

In order to develop his model, Altman (1968) chose a sample of sixty-six (-66-) manufacturing companies listed in the Stock Exchange Market, thirty-three (-33-) of which had already filed a bankruptcy petition, in a 


\section{Articles}

period of time between 1946 to 1965 , whilst the remaining thirty-three (-33-) were still operating. After having tested twenty-two (-22-) financial ratios related to bankruptcy prediction, Altman finally ended up with

$Z-$ score $=1.2 \cdot x_{1}+1.4 \cdot x_{2}+3.3 \cdot x_{3}$

Where:

$x_{1}=$ Working capital/Total assets,

$x_{2}=$ Retained earnings/Total assets,

$x_{3}=$ EBIT/Total assets,

$x_{4}=$ Market value of equity/Book value of total debt,

$x_{5}=$ Sales/Total assets.

The aforementioned model of Altman (1968) states that the variable $x_{3}=$ EBIT/ Total assets is the most important followed by the variable $x_{5}=$ Sales/Total assets, $x_{4}$, $x_{2}$ and $x_{1}$. The bankruptcy threshold was set at 1.81 with bankrupt companies presenting z-scores below this value whilst the clear nonbankruptcy threshold was set at 2.675 with non- bankrupt companies presenting z-scores above this value. The zone between the two five (-5-) of them being either statistically independent or highly inter-correlated with the other variables of the sample. Altman's (1968) model received the following mathematical form:

$+0.6 \cdot x_{4}+1.0 \cdot x_{5}{ }^{1}$

values [1.81, 2.675] was defined as "grey area" (Altman, 1968).

As the original Altman's (1968) model considered companies listed in the Stock Exchange Market thus limiting the use of the model to this type of firms, Altman revisited his model and developed a new model for private firms not listed in the Stock Exchange Market in 1983. The new Altman's (1983) model consisted of the same variables as the original one with the $x_{4}=$ Market value of equity/Book value of total debt, variable being replaced with the ratio of $x_{4}=$ Book value of equity/Total Liabilities. Hence, the new Altman's (1983) model for private firms not listed in the Stock Exchange Market takes the form:

$$
Z^{\prime}-\text { score }=0.717 \cdot x_{1}+0.847 \cdot x_{2}+3.107 \cdot x_{3}+0.420 \cdot x_{4}+0.998 \cdot x_{5}
$$

Where:

$x_{1}=$ Working capital/Total assets,

$x_{2}=$ Retained earnings/Total assets

$x_{3}=$ EBIT/Total assets

$x_{4}=$ Book value of equity/Total Liabilities

$x_{5}=$ Sales/Total assets

The aforementioned new model Altman (1983) states that the variable $x_{3}=\mathrm{EBIT} /$ Total assets is the most important followed by the variable $x_{5}=$ Sales/Total assets, $x_{4}$, $x_{2}$ and $x_{1}$. The bankruptcy threshold was set at 1.23 with bankrupt companies presenting $Z^{\prime}$-scores below this value whilst the clear non- bankruptcy threshold was set at 2.9 with non- bankrupt companies presenting z-scores above this value. The zone between the two values [1.23 - 2.9] was defined as "grey area".

The original Altman's model (1968) was recalculated for non-manufacturing companies and for firms operating in emerging markets in another study, Altman (2000). This new model Altman (2000) is comprised of the same variables except for the $x_{5}=$ total sales / total assets, which was omitted in order to minimize the potential industry effect. The mathematical form of the model Altman (2000) is as follows:

$Z^{\prime \prime}-$ score $=6.56 \cdot x_{1}+3.26 \cdot x_{2}+6.72 \cdot x_{3}+1.05 \cdot x_{4}$

1 The original equation was $Z-$ score $=0.012 \cdot x_{1}+0.014 \cdot x_{2}+0.033 \cdot x_{3}+0.006 \cdot x_{4}+0.999 \cdot x_{5}$ and after multiplying the ratios $x_{1}$ to $x_{4}$ by one hundred (-100-), in order to form a more convenient in terms of calculations model, Altman's original model took the form shown in eq. 1 (Altman, 2000) 


\section{Articles}

Where:

$x_{1}=$ Working capital/Total assets

$x_{2}=$ Retained earnings/Total assets

$x_{3}=$ EBIT/Total assets

$x_{4}=$ Book value of equity/Total Liabilities

The $Z^{\prime \prime}$ - score of the new model Altman (2000) states that the variable $x_{3}=$ EBIT/ Total assets is the most important followed by
The Effect of the Cash Conversion Cycle on the Z-scores of Fresh Milk Companies in Greece

the variables $x_{1}, x_{2}$ and $x_{4}$. The $Z$ " -scores are then projected to bond rating equivalents according to Altman \& Hotchkiss (2006).

The Altman (2000) model was recalibrated for emerging markets by adding the constant term of 3.25 in order to standardize a $Z^{\prime \prime}$ -score equal to zero to the $D$ rating bond equivalent (Altman \& Hotchkiss, 2006, p. 248).

$Z^{\prime \prime}-$ score $=3.25+6.56 \cdot x_{1}+3.26 \cdot x_{2}+6.72 \cdot x_{3}+1.05 \cdot x_{4}$

The original Altman (1968) model as well as the revised ones of 1983 and 2000 have been extensively used in research applied on various countries, various industries and various periods of time. The original Altman model (1968) has been applied by several researchers, such as (a) Mantziaris (2015) on forty (40) Greek companies listed in the Athens Stock Exchange, twenty (20) of which had gone bankrupt with the remaining twenty (20) still viable, using data between 2005 and 2013, following the same methodology, in order to investigate if Altman's model could be efficiently applied to predict bankruptcy of Greek companies in the period of economic recession, (b) Stepanyan (2014) on the seven (7) largest American Airline firms in a period of study between 2007 and 2012, in order to investigate the industry's vulnerability to bankruptcy after the 09/11 and the global financial crisis, events which led a lot of American airline companies to file for bankruptcy protection, (c) Fawad, lqtidar, Shakir and Madad (2014) on twenty one (21) textile firms, nine (9) of which had gone bankrupt, all listed in the Karachi Stock Exchange Market, in order to predict failure in one of Pakistan's largest industries, the textile industry. All researchers concluded that the model Altman (1968) had satisfactory prediction levels but needed to be recalibrated in order to take into account the specific economic conditions prevailing in the industry, the country and the time period applied.
The revised Altman (1983) model was applied by El Khoury and Al Beiano (2013) on eleven (11) private manufacturing firms in Lebanon which had previously been granted a bank loan and their research concluded that the model could be used as a barometer in classifying companies stating that structural differentiations between the USA and Lebanese economies and accounting reporting standards as well as limitations relevant to the sample size and the length of the data time series affected the study. The revised Altman (2000) model and the Distance to Default model were applied by Gatomati (2016) on 2,914 micro, small and medium size Greek firms using data from the period between 2007 to 2014, in order to assess the forecasting ability of both models and the effect of various variables including a time dummy variable before and after the economic crisis and eventually assess the tested companies' access to bank loans. Patanwala, (2016) applied the revised Altman model (2000) on five (5) Indian fast moving consumer goods (FMGC) firms over a period of time between 2013 and 2015. Hayes, Hodge and Hughes, (2010) applied Altman's (2000) revised model on a sample of eight (8) bankrupt public sector retail firms and eight (8) non financially healthy ones over a period between 2007 and 2008 in order to investigate if the high and at the time increasing number of bankruptcy petitions in the public sector retail firms could be predicted. Wang Yi (2012) 


\section{Articles}

applied Altman's (2000) revised model on a sample of 40 real estate firms listed in the Shanghai and Shenzhen A- Stock Exchange market, ten (10) of which were in distress and the remaining thirty (30) were operating satisfactorily in the Chinese real estate sector, in order to predict potential future bankruptcy of the firms in the sector due to the global financial crisis. The application of Altman's revised models (1983) and (2000) showed that the models could be satisfactorily used as solvency prediction tools, with higher accuracy results closer to the default year.

Comparative analysis of the use of the original Altman (1968) model along with the revised (1983) model and the (2000) model took place in the work of Boda and Uradnicek (2016), Kral et al (2016) and Rybárová et al (2016) in order to assess the prediction accuracy of Altman's models (1968), (1983) and (2000) on Slovak companies. Meeampol, Lerskullawat, Wongsorntham, Srinammuang, Rodpetch, and Noonoi (2014) applied both Altman's original model (1968) and Altman's (2000) revised on a sample of thirty-one (31) firms listed in Thailand Stock Exchange Market, in order to investigate the potential financial distress of Thai companies and the applicability of both Altman models to the specific set of data. Kaplinski (2008) applied Altman's original model from Altman (1968) and the revised models Altman (1983) and Altman (2000) on construction firms listed in the Warsaw Stock Exchange Market in order to investigate if Altman's models could be efficiently applied in the Polish economy, as the significance of bankruptcy prediction models is highlighted by the fact that according to Polish legislation for a company to participate in a tender of public work construction it should have an Altman's (2000) Z-score not less than 2.99. Grice and Ingram (2001) conducted a research applying Altman's original model (1968) on a large number of companies in order to address issues related to the prediction ability of Altman's original model when (a) applied at a time period different to the original model's one, (b) applied on non-manufacturing firms and (c) if the model can predict financial distress conditions other than bankruptcy.

Finally, Altman, Iwanicz-Drozdowska, Laitinen and Suvas (2014), reviewed the literature on the efficacy and importance of the Altman Z-Score bankruptcy prediction model globally as well as its applications in finance and related areas. The review was based on an analysis of 34 scientific papers published from the year 2000 onwards in leading financial and accounting journals. A large international sample of firms from 32 European and three non-European countries was used in order to assess the classification performance of the model in bankruptcy and distressed firm prediction. Except for the U.S. and China, the firms in the sample were private and covered non-financial companies across all industrial sectors. The version of the Z-Score model developed by Altman (1983) for private manufacturing and non-manufacturing firms (Z''-Score Model) was used in the study. The research above concluded that Altman's models could be used satisfactorily as rating tools but they should be recalibrated in order to take into account the specific country and industry prevailing economic conditions.

Regarding the dairy industry, Bindu and Subrahmanyam, (2012) studied the financial health of five selected industries in the area of Andhra Pradesh in India, as the country's dairy sector has been showing significant development since the beginning of the decade of 2000 and the Indian market is one of the largest for dairy products in the world comprising of 1 billion people, an immense territory and abundant resources, whilst Bindu, Subrahmanyam and Bhat, (2015) applied Altman's original Z-score model 


\section{Articles}

(1968) on eleven (11) dairy firms of the area of Andhra Pradesh in India, using financial data for a period of time between 2005 and 2012 in order to study their financial performance and Gawali and Gadekar (2017) performed a comparative study of the financial health of two co-operative milk processing firms randomly selected out of fourteen (14) operating in the District of Ahmednagar in Maharashtra, India.

\subsection{The Cash Conversion Cycle}

The cash conversion cycle (CCC) is another liquidity indicator alongside the current and quick ratios as Lyroudi and McCarty (1993) state. The cash conversion cycle aims to assess how effectively a firm manages its working capital and actually measures the time period in days in which a firm converts its inventories and accounts receivable into cash.

The production cycle of an item starts with the purchase of raw materials, their transformation into the final product which is then sold to clients and via them the product reaches the final consumer. As credit is mostly used between firms for the purchase of raw materials and sale to clients, Cash is recovered with a time delay. Cash is then used for the purchase of new raw materials or the payoff of short term liabilities. The cash conversion cycle provides useful information about the time period capital is confined by the operational processes of the firm.

According to Lyroudi and McCarty (1993), the cash conversion cycle is defined as the sum of the receivables conversion period (RCP) plus the inventory conversion period (ICP) minus the payment deferral period (PDP), as follows:

$\mathrm{CCC}=\mathrm{RCP}+\mathrm{ICP}-\mathrm{PDP}$

Where:

$\mathrm{RCP}=$ receivables conversion period $=$ 360 / Accounts Receivable Turnover
The Effect of the Cash Conversion Cycle on the Z-scores of Fresh Milk Companies in Greece

IGP = inventory conversion period $=360 /$ Inventory Turnover

$\mathrm{PDP}=$ payment deferral period $=360 \mathrm{I}$ Payables Turnover

$\mathrm{CCC}=360 *(\mathrm{AR} /$ Sales $)+360 *$

*(Inventory/CGS) - 360*(CL/X)

where:

$\mathrm{AR}=$ Accounts Receivable

CGS $=$ Cost of Goods Sold

$\mathrm{CL}=$ Current liabilities

$\mathrm{X}=\mathrm{CGS}+$ Expenses + Interest + Labor + Advertising + Insurance + Travel + Salaries Depreciation.

The shorter the cash conversion cycle is, the more flexible and efficient a firm can be in managing its working capital. During economic recession, cash shortage from the market has been evident and suffocating the operational processes of most firms across the production sectors in Greece. At the same time the payoff of short- and long-term liabilities is delayed bringing a large number of companies to insolvency and finally to bankruptcy.

Hager (1976) presented for the first time the concept of the cash conversion cycle (CCC). Richards and Laughlin (1980) suggested that a CCC analysis should be used in addition to the traditional but static liquidity ratios, the current and quick ratios, because it provides dynamic insights. Nordgren (1981) introduced a cash cycle analysis, based on the asset conversion cycle and the liability cycle. Belt (1985) examined the trends of the CCC and its components during the period 1950-1983 for a sample of US companies. He found that retailing and wholesaling firms both had cash conversion cycles shorter than those of manufacturing firms. Besley and Meyer (1987) for a sample of US companies for the period 1969-1983 found that the cash conversion cycle (CCC) was most correlated with the average age of 


\section{Articles}

inventory and least correlated with the age of spontaneous credit. The CCC differed from industry to industry, but did not vary from year to year. Kamath (1989) focused on large US firms in six retail industries for the period 1970-1984 and found that the current and quick ratios were negatively correlated with the CCC and the CCC was negatively related to the profitability ratios, while the current and quick ratios were not negatively related to those. Gentry, Vaidyanathan and Lee (1990) developed a weighted cash conversion cycle (WCCC) which focused on the real resource commitment of working capital, and decomposed inventories into three parts instead of one as the others have done before and found that the WCCC was very sensitive to the size of payables.

Lyroudi and McCarty (1993) for a sample of small (capitalization under $\$ 1$ million) US companies for the period 1984 to 1988 found that the CCC was negatively related to the current ratio, to the inventory conversion period and to the payables deferral period, but positively related to the quick ratio and to the receivables conversion period. Moss and Stine (1993) for a sample of US retail firms for the period 1971 to 1990 found that larger retail firms had shorter CCCs, implying that they had better working capital management. They also found that the CCC was positively and significantly related to the current and quick ratios, implying a large investment in working capital which could cause future problems. Schilling (1996) regarded the CCC as a working capital evaluation technique depicting better a company's average liquidity position. Gallinger (1997) suggested that we should use only the CCC as a more accurate measure of liquidity versus the current and quick ratios. Lyroudi and McCarty (1999) for the top 350 firms listed in the London Stock Exchange during the period 1993 to 1997 found that the CCC was significantly positively related to the current and quick ratios, in contrast to their hypothesis.

Lyroudi and Lazaridis (2000) for a sample of the food industry in Greece found that there was a significant positive relationship between the CCC and the more traditional current and quick ratios and the return on assets, the net profit margin but had no linear relationship with the leverage ratios. Farris and Hutchison (2002) emphasized the significance of the CCC from an accounting and cash management point of view. Wang (2002) studied firms from Japan and Taiwan for the period 1985-1996 and found a negative relation between the CCC and profitability as measured by both the return on assets and the return on equity. Yucel and Kurt (2002) for a sample of Turkish companies found that the CCC was positively related to liquidity ratios and negatively related to profitability ratios ROE and ROA. Deloof (2003), studied the 1,009 most important firms in Belgium, regarding their profitability and their working capital management, measured by the CCC and found a significant negative relation between gross operating income (profitability) and the number of days accounts receivables, inventories and accounts payable of Belgian firms.

Shah and Sana (2006) examined the relationship between the CCC and the profitability for a sample of seven listed companies in Oil and Gas sector of Pakistan for the period 2001-2005 and found a negative relationship between gross profit margin and number of day's inventory outstanding, as well the number of day's accounts receivables, cash conversion cycle and sales growth, while the relationship between gross profit margin and the number of day's accounts payables was positive. Apergis, Lyroudi and McCarty (2007), for a sample of 225 large UK companies (in retail services, general manufacturing and consumer goods), listed 


\section{Articles}

on the London Stock Exchange for the period 1993-1999, investigated the relationship and causality of the company's liquidity with its profitability and indebtedness. When liquidity was measured by the CCC it caused profitability, but the profitability did not cause liquidity. Raheman and Nasr (2007) studied 94 Pakistani firms listed on Karachi Stock Exchange for the 1999 - 2004 period, and found that the relationship between the average collection period, the inventory turnover in days, the average payment period and the cash conversion cycle were negative and significant with the firm's profitability. Garcia-Teruel and Martinez-Solano (2007) examined 8,872 small and medium-sized small and medium sized Spanish firms for the period 1996-2002 and found a significant negative relation between the profitability and the number of days accounts receivables and days of inventory outstanding. Sen and Oruk (2009) for a sample of 49 firms traded in ISE (Istanbul Stock Exchange) for the period 19932007 found a significant negative relationship between the CCC, the net working capital, the current ratio, the accounts receivables period, the inventory period and the return on total assets ratio.

Nobanee and Al Hajjar (2009a) studied a sample of 2,123 Japanese non-financial firms listed in the Tokyo Stock Exchange for the period 1990-2004 and found that the relationship between the CCC and profitability was negative. Furthermore, they found that the CCC of their sample's firms was smaller than the CCC of American and European ones. In another survey, Nobanee and $\mathrm{Al}$ Hajjar (2009b) studied a sample of 5,802 nonfinancial US firms listed in the New York Stock Exchange for the period 1990-2004 and found that profitability and operating cash flow of their firms can be increased by shortening the CCC mostly by shortening the receivables collection period. Finally, in a third study of
The Effect of the Cash Conversion Cycle on the Z-scores of Fresh Milk Companies in Greece

American non-financial companies for the period 1990-2004, Nobanee and Al Hajjar (2009c) found a negative relationship between the CCC and the payables deferral period on the firm's profitability, while the relationship between the receivables conversion period and the inventory conversion period on profitability was positive.

Mathuva (2010) used a sample of 30 firms listed on the Nairobi Stock Exchange (NSE) for the period 1993-2008 and found that the cash conversion cycle and the firm's leverage had a negative relationship with the firm's profitability, while the relationship between the firm's size and profitability was positive. Gill et al. (2010) for US companies found a statistically significant relationship between the CCC and the gross operating profit. Charitou et al. (2010) showed that the cash conversion cycle and all its components were associated with the firm's profitability for the market of Cyprus. Dong and Su (2010) used a sample of 130 listed Vietnamese firms, another developing market, for the period 2006-2008 and found that the CCC, the inventory and the receivables conversion period were related negatively to profitability. Mohamad and Saad (2010) found for Malaysian firms that the three components the CCC, the current asset to current liabilities ratio and the current liabilities to total asset ratio showed negative significant relations with the Tobin $Q$.

Alipour (2011) for a sample of 1,063 Iranian companies found a negative significant relation between the CCC and the gross operating profit. Ebben and Johnson (2011) found that firms in the USA with more efficient CCC were more liquid, required less debt and equity financing, and had higher returns. Grosse, Ruyken et al (2011) analyzed a sample of 1,274 firms from 12 industries from 2000 to 2005 in five countries (Canada, England, France, Germany, USA), and found a significant negative relationship between 


\section{Articles}

the CCC and the return on capital employed (ROCE).

Sharma and Kumar (2011) for a sample of 263 non-financial BSE 500 firms listed on the Bombay Stock (BSE), found that there was a positive relationship between the profitability and the CCC. Lyroudi and Rychter (2012) for a sample of non-financial Polish companies found a strong positive relation between the CCC and the current and quick ratios. Regarding the liquidity-profitability relationship, the CCC had no linear relationship with any of the profitability measures. Anser and Malik (2013), for Pakistani listed firms, found that the CCC had an inverse and significant association with the profitability of manufacturing companies. Yazdanfar and Ohman (2014) investigated the impact of the CCC on performance for small and medium sized Swedish companies and found that there was a significant and negative relationship. Upadhyay, Sen and Smith (2015) examined the effect of the CCC on the US hospitals' profitability for a sample of US hospitals in Washington State and found that only the CCC component of the inventory conversion period had a negative impact on profitability. Garanina and Petrova (2015) found an inverse relationship between liquidity as measured by the cash conversion cycle and profitability as measured by the return on net operating assets (RNOA) for 720 Russian companies. Their study also indicated a positive relationship between the current ratio as a liquidity measure and the RNOA. Zakari and Saidu (2016), for Nigerian companies found a significant positive relationship between the CCC and corporate profitability. Sugathadasa (2018) found that the relationship between the CCC and profitability of manufacturing sector organizations listed in the Colombo Stock Exchange as measured by the ROA was positive, while negative between payable conversion periods on while the relationship between the CCC and the profitability ratio ROE was negative. Cristea and Cristea (2018) studied the relation of the CCC and profitability in a sample of non-financial companies listed on the Bucharest Stock Exchange and found that it was negative. Therefore, managers could improve their firm's profitability by decreasing the number of days in the CCC.

As it can be observed, the relation of the cash conversion cycle and the firm's viability measured by the Z-score has not been yet examined to our knowledge. Our study is original in this aspect and enriches the literature on the issue of the cash conversion cycle, examining another aspect.

\section{METHODOLOGY}

The dairy companies "THESS GALA PIES", "DELTA" and "TRIKKI" will be tested using (a) the Altman (1983) Z-score model for non - public firms (Equation 2), as the companies do not negotiate their shares on the Stock Exchange Market and (b) the Altman (2000) Z-score model for non-manufacturing companies and for firms operating in emerging markets (Equation 4), as Greece was listed as an emerging market in June 2013 by Morgan Stanley Capital International, according to Dunkley (2013). According to Morgan Stanley Capital International, the economic crisis that hit Greece in 2008 led to a continuous debt crisis and raised currency issues that disrupted and damaged the country's economy to such a degree that it was untenable for the country's economy to be listed among the world's most functional economies according to Phillips (2013). The data for the Z-score estimate is derived from the aforementioned companies' balance sheets of the years 2012 up to 2016, which were available on the internet on the companies' web sites where they were published.

The Cash Conversion Cycle will be estimated for the dairy companies "THESS 


\section{Articles}

GALA PIES", "DELTA" and "TRIKKI" using Equation 5, as developed by Lyroudi and McCarty (1993). As it can be observed, the cash conversion cycle is comprised of the sum of three activity ratios. According to Eriotis (2005), these ratios are calculated as follows: For the calculation of the ratio of the Accounts Receivable Turnover the average of the accounts receivable at the beginning and at the end of the financial year should be taken into account as the ending accounts receivable do not present the real accounts receivable during the accounting period. Regarding the Inventory Turnover ratio, the average of inventories at the beginning and the end of the accounting period is taken into account. A similar perspective is applied for the calculation of the payables turnover ratio, taking into account the average current liabilities at the beginning and the end of the accounting period. Hence, two sets of estimated values for the CCC are used: (a) CCC (1) using the ending values of accounts receivable, inventories and current liabilities and (b) CCC (2) using the average values at the beginning and the end of the accounting period of accounts receivable, inventories and current liabilities.
The Effect of the Cash Conversion Cycle on the Z-scores of Fresh Milk Companies in Greece

The relationship between the cash conversion cycle (CCC) and the estimated Z - scores is investigated, using the regression analysis tool of Microsoft Excel, plotting the Z- scores as derived applying the non-public firms model (Z-SCORE 1) and the emerging markets model (Z-SCORE 2) against CCC (1) and CCC (2).

\section{DATA USE AND SOURCES}

\subsection{Estimate of z-score and cash conversion cycle for "THESS GALA PIES"}

In order to define the variables that form the Z-score components of the Altman (1983) model (Equation 2) and the Altman (2000) model (Equation 4), data from the balance sheets and income statements of the years 2012, 2013, 2014, 2015, for the company "THESS-GALA PIES" are used. Hence, working capital is defined as the difference between current assets and short-term liabilities, whilst total assets, total liabilities, retained earnings, and book value of equity are directly derived from the balance sheets and EBIT and sales directly derived from the income statements. The data used is presented in Table 1 as follows:

Table 1: Data derived from balance sheets for the estimation of the Z-score components for the non public firms

\begin{tabular}{|l|l|l|l|l|}
\hline Z-score components & $\mathbf{2 0 1 2}$ & $\mathbf{2 0 1 3}$ & $\mathbf{2 0 1 4}$ & $\mathbf{2 0 1 5}$ \\
\hline Current Assets & $1,698,326.55$ & $5,581,569.99$ & $4,555,010.07$ & $3,831,902.26$ \\
\hline Short-term Liabilities & $1,412,618.37$ & $4,531,417.05$ & $4,426,424.10$ & $4,928,112.10$ \\
\hline Accruals & $24,109.95$ & $49,683.62$ & $66,197.27$ & 0.0 \\
\hline Current Liabilities & $1,436,728.32$ & $4,581,100.67$ & $4,492,621.37$ & $4,928,112.10$ \\
\hline Working Capital & $261,598.23$ & $1,000,469.32$ & $62,388.70$ & $1,096,209.84$ \\
\hline Total Assets & $1,707,288.02$ & $5,609,434.15$ & $5,844,607.99$ & $7,323,413.60$ \\
\hline Retained Earnings & $174,203.73$ & 0 & $282,692.11$ & $311,181.52$ \\
\hline EBIT & $237,994.70$ & $773,795.92$ & $507,643.23$ & $223,599.81$ \\
\hline Sales & $16,458,507.47$ & $23,044,851.07$ & $24,731,182.49$ & $23,144,809.26$ \\
\hline Book value of Equity & $270,559.70$ & $1,028,333.48$ & $1,351,986.62$ & $1,371,347.43$ \\
\hline Total Liabilities & $1,436,728.32$ & $4,581,100.67$ & $4,492,621.37$ & $5,952,066.17$ \\
\hline
\end{tabular}

(Source: Balance sheets and income statements of the company "THESS GALA PIES") 


\section{Articles}

As total liabilities are defined the sum of short term liabilities, long term liabilities and transitional accounts, whilst as book value of equity is defined the total of shareholder's capital. After applying the Altman (1983) Z-score model for non-publicly traded companies (Equation 2) and the Altman (2000) Z-score model for non-manufacturing companies and emerging markets (Equation 4), using the data of Table 1, we get the following Z-score values for "THESS GALA PIES", presented in Table 2:

Table 2: "THESS GALA PIES" Z-score estimates for the years 2012 - 2015 using the Altman (1983) model for non-publicly traded firms and the Altman (2000) model for non-manufacturing firms or for emerging markets

\begin{tabular}{|l|l|l|l|l|}
\hline$Z$-score parameters & 2012 & 2013 & 2014 & 2015 \\
\hline$Z^{\prime}$-score (1983) & 10.329 & 4.751 & 4.668 & 3.274 \\
\hline$Z^{\prime \prime}$-score (2000) & $5.759(\mathrm{BBB})$ & $5.583(\mathrm{BBB}-)$ & $4.395(\mathrm{~B}+)$ & $2.869(\mathrm{CCC})$ \\
\hline
\end{tabular}

As it has been mentioned, the bankruptcy and safety threshold of Altman's (1983) model for non-publicly traded firms were set at 1.23 and 2.9, accordingly. Based on the results in Table 2, the company shows an excellent performance as all estimated Z-scores for the period between 2012 and 2015 are well above the safety threshold, i.e 2.9. The Z-scores for emerging markets are projected to bond rating equivalents with a $Z^{\prime \prime}$-score equal to zero being standardized to the $D$ rating bond equivalent (Altman and Hotchkiss, 2006, pg. 248). Hence, the rating of the company THESS-GALA PIES for 2012 is BBB, falls to BBB- for 2013, to B+ for 2014 and CCC for 2015.

Both models present a downward slope of the estimated Z-scores which is due to (a) the increase of current liabilities towards current assets hence leading to negative working capital, (b) the decrease of EBIT and the increase of total assets, as the company is still expanding, leading to a decrease of the ratio EBIT/Total Assets. Regarding the non-publicly traded firms Z-score model, the
X5 component which comprises of Sales to Total Assets contributes significantly to the final result as the Sales are almost triple the Total Assets of the company. As the company expands the aforementioned ratio decreases. In the present case, the sales of the company have increased by 1.4 between 2012 and 2015 whilst the total assets have increased by 4.29 in the same period.

As it has already been mentioned, the cash conversion cycle is calculated in order to estimate its effect on the Z-scores of the company. As the estimate of the Z-scores did not take into account any average financial magnitude, the estimate of the cash conversion cycle will take place using both the annual values as well as the average values at the beginning and the end of the accounting period. The balance sheet and income statement items that are used for the estimation of the cash conversion cycle of the company THESS GALA PIES for the period between 2012 and 2015 are presented in the Table 3 as follows: 
Table 3: "THESS GALA PIES" Balance sheet and income statement items for the estimate of the cash conversion cycle ${ }^{2}$

\begin{tabular}{|l|l|l|l|l|}
\hline & $\mathbf{2 0 1 2}$ & $\mathbf{2 0 1 3}$ & $\mathbf{2 0 1 4}$ & $\mathbf{2 0 1 5}$ \\
\hline Receivables & $1,399,536.84$ & $5,536,166.20$ & $3,764,926.65$ & $3,521,325.17$ \\
\hline Inventory & $168,904.50$ & $10,361.08$ & $668,906.29$ & $121,966.50$ \\
\hline Sales & $16,458,507.47$ & $23,044,851.07$ & $24,731,182.49$ & $23,144,809.26$ \\
\hline Cost of goods sold & $15,982,026.14$ & $21,153,640.06$ & $22,347,045.25$ & $19,510,605.94$ \\
\hline average receivables & $1,399,536.84$ & $3,467,851.52$ & $4,650,546.43$ & $3,643,125.91$ \\
\hline average inventory & $168,904.50$ & $89,632.79$ & $339,633.69$ & $395,436.40$ \\
\hline CL & $1,436,728.32$ & $4,581,100.67$ & $4,492,621.37$ & $4,928,112.10$ \\
\hline average CL & $1,436,728.32$ & $3,008,914.50$ & $4,536,861.02$ & $4,710,366.74$ \\
\hline CGS & $15,982,026.14$ & $21,153,640.06$ & $22,347,045.25$ & $19,510,605.94$ \\
\hline Expenses & $238,486.63$ & $1,117,415.09$ & $3,703,862.98$ & $1,920,471.77$ \\
\hline Interest & $7,231.83$ & $4,769.66$ & $37,371.30$ & $159,288.67$ \\
\hline Depreciation & $15,003.49$ & $15,530.30$ & $115,880.50$ & $115,880.50$ \\
\hline X & $16,212,741.11$ & $22,260,29451$ & $25,972,399.03$ & $21,474,485.88$ \\
\hline
\end{tabular}

In Table 4 that follows, the estimates of the cash conversion cycle using the ending values (CCC (1)) and the average values

at the beginning and end of the accounting period (CCC (2)) are presented.

Table 4: Estimates of the cash conversion cycle using the ending values and the average values at the beginning and end of the accounting period ${ }^{3}$

\begin{tabular}{|l|l|l|l|l|}
\hline & 2012 & 2013 & 2014 & 2015 \\
\hline $\operatorname{CcC}(1)$ & 3 & 13 & 3 & -26 \\
\hline $\operatorname{CCC}(2)$ & 3 & 7 & 10 & -15 \\
\hline
\end{tabular}

\subsection{Estimate of z-scores and cash conversion cycle for "DELTA"}

In this part we focus on the market leader of dairy products, the company "DELTA". In order to define the variables that form the Z-score components of the Altman (1983) model (Equation 2) and the Altman (2000) model (Equation 4), data from the balance sheets and income statements of the years 2012, 2013, 2014, 2015 and 2016 were used as in the former case of "THESS GALA PIES". The data used are presented in Table 5 as follows expressed in thousands of euros:

Table 5: Data derived from "DELTA" financial statements for the estimate of the Z-score components

\begin{tabular}{|l|l|l|l|l|l|}
\hline Z-score components & 2012 & 2013 & 2014 & 2015 & 2016 \\
\hline Current Assets & $116,587.00$ & $115,333.00$ & $100,049.00$ & $109,375.00$ & $92,959.00$ \\
\hline Current liabilities & $179,838.00$ & $197,123.00$ & $173,702.00$ & $193,517.00$ & $182,175.00$ \\
\hline
\end{tabular}

\footnotetext{
2 Source: "THESS GALA PIES" balance sheets and income statements. Calculations derived by the authors
}

${ }^{3}$ Calculations derived by the authors 
Articles

\begin{tabular}{|l|l|l|l|l|l|}
\hline Working Capital & $-63,251.00$ & $-81,790.00$ & $-73,653.00$ & $-84,142.00$ & $-89,216.00$ \\
\hline Total Assets & $414,165.00$ & $368,407.00$ & $368,301.00$ & $353,361.00$ & $339,358.00$ \\
\hline Retained Earnings & $-123,538.00$ & $-172,635.00$ & $-194,656.00$ & $-208,131.00$ & $-218,429.00$ \\
\hline EBIT & $-42,922.00$ & $-43,499.00$ & $-22,781.00$ & $-12,009.00$ & $-15,588.00$ \\
\hline Sales & $281,568.00$ & $279,385.00$ & $290,319.00$ & $261,281.00$ & $238,534.00$ \\
\hline Book value of Equity & $198,580.00$ & $149,761.00$ & $127,740.00$ & $114,265.00$ & $111,879.00$ \\
\hline Total liabilities & $215,585.00$ & $218,540.00$ & $240,668.00$ & $239,096.00$ & $227,479.00$ \\
\hline
\end{tabular}

Source: Balance sheets and income statements of the company "DELTA".

After applying the Altman (1983) Z-score $\mid$ emerging markets (Equation 4), using the data model for non-publicly traded companies (Equation 2) and the Altman (2000) Z-score model for non-manufacturing companies and for "DELTA", presented in Table 6:

Table 6: "DELTA" Z'-score estimates for the years 2012 - 2016 using the Altman (1983) model for non-publicly traded firms

\begin{tabular}{|l|l|l|l|l|l|}
\hline$Z^{\prime}$-score parameters & 2012 & 2013 & 2014 & 2015 & 2016 \\
\hline$Z^{\prime}$-score (1983) & 0.381 & 0.122 & 0.226 & 0.163 & 0.032 \\
\hline$Z^{\prime \prime}$-score (2000) & $1.439(\mathrm{CCC}$-) & $0.023(\mathrm{D})$ & $0.167(\mathrm{D})$ & $-0.171(\mathrm{D})$ & $-0.597(\mathrm{D})$ \\
\hline
\end{tabular}

As it has been mentioned, the bankruptcy threshold was set at 1.23 , whilst the safety threshold was set at 2.9, "DELTA", although the leader in the fresh milk market, presents $Z^{\prime}$-scores well below the bankruptcy threshold since the company tends to accumulate losses thus decreasing its retained earnings component. It is also noticed that the $Z^{\prime}$ score tends to diminish as the company's current assets decrease and its liabilities increase. Furthermore, the company presents decreasing sales, decreasing total assets and equity and increasing long term liabilities. "DELTA" constitutes a company of the Vivartia Group since 2006 when the group was established after the merging of "DELTA MILK INDUSTRY", "GOODY'S", "CHIPITA INTERNATIONAL" and "GENIKI TROFIMON S.A.". The enlarged company assumed negotiating its shares in the Athens Stock Exchange in 2010. As a milk company "DELTA" has been present in Greece since 1952. The insolvency of the Marinopoulos
Carrefour Supermarket Chain has damaged the financial situation of the firm (VIVARTIA, 2018). The application of the Altman (2000) emerging markets model (Equation 4) shows that the company performs very poorly as being equivalent to CCC- and D bond rating. Both models show a very poor performance of the leading company which could be seen as a type II error, i.e. the company presenting low Z"scores but still being viable. It should be noted that as "DELTA" forms part of the Vivartia Group in which other participating firms such as "BARBA STATHIS" present profits. Therefore, the viability of the company "DELTA" is sustained all the way through the economic crisis period by the mother company Vivartia Group.

The financial data for "DELTA", as they were retrieved from the company's financial statements and elaborated in order to estimate the Cash Conversion Cycle are presented in Table 7. 
Table 7: "DELTA" financial data for the estimate of the cash Conversion Cycle ${ }^{4}$

\begin{tabular}{|l|l|l|l|l|l|}
\hline & $\mathbf{2 0 1 2}$ & $\mathbf{2 0 1 3}$ & $\mathbf{2 0 1 4}$ & $\mathbf{2 0 1 5}$ & $\mathbf{2 0 1 6}$ \\
\hline Cash & $15,476.00$ & $9,190.00$ & $17,777.00$ & $20,031.00$ & $15,256.00$ \\
\hline Securities & $27,442.00$ & $20,661.00$ & $20,029.00$ & $15,787.00$ & $10,533.00$ \\
\hline Receivable & $48,630.00$ & $50,318.00$ & $62,718.00$ & $57,543.00$ & $51,746.00$ \\
\hline TOTAL REC & $76,072.00$ & $70,979.00$ & $82,747.00$ & $73,330.00$ & $62,279.00$ \\
\hline Inventory & $25,039.00$ & $19,880.00$ & $14,809.00$ & $16,014.00$ & $15,424.00$ \\
\hline Sales & $281,568.00$ & $290,319.00$ & $279,385.00$ & $261,281.00$ & $238,534.00$ \\
\hline Cost of goods sold & $228,010.00$ & $225,778.00$ & $226,549.00$ & $194,471.00$ & $181,213.00$ \\
\hline average receivables & $76,072.00$ & $73,525.50$ & $76,863.00$ & $78,038.50$ & $67,804.50$ \\
\hline average inventory & $25,039.00$ & $22,459.50$ & $17,344.50$ & $15,411.50$ & $15,719.00$ \\
\hline CL & 179,838 & $173,702.00$ & $197,123.00$ & $193,517.00$ & $182,175.00$ \\
\hline average CL & 179,838 & $176,770.00$ & $185,412.50$ & $195,320.00$ & $187,846.00$ \\
\hline CGS & $228,010.00$ & $225,778.00$ & $226,549.00$ & $194,471.00$ & $181,213.00$ \\
\hline Expenses & $81,634.00$ & $73,998.00$ & $77,078.00$ & $73,072.00$ & $69,251.00$ \\
\hline Interest & $21,546.00$ & $27,390.00$ & $13,849.00$ & $10,229.00$ & $16,176.00$ \\
\hline Depreciation & $16,191.00$ & $15,386.00$ & $15,076.00$ & $15,526.00$ & $15,266.00$ \\
\hline X & $314,999.00$ & $311,780.00$ & $302,400.00$ & $262,246.00$ & $251,374.00$ \\
\hline
\end{tabular}

In Table 8 two estimates of the Cash Conversion Cycle are presented, CCC (1) using the ending values of Accounts Receivable, Inventory and Current Liabilities and CCC (2) using the average values of the aforementioned magnitudes at the beginning and the end of the accounting year.

Table 8: Estimates of the cash conversion cycle using the ending values and the average values at the beginning and end of the accounting period for "DELTA"

\begin{tabular}{|l|l|l|l|l|l|}
\hline & 2012 & 2013 & 2014 & 2015 & 2016 \\
\hline $\operatorname{CCC}(1)$ & -69 & -81 & -105 & -135 & -136 \\
\hline $\operatorname{CCC}(2)$ & -69 & -77 & -94 & -132 & -135 \\
\hline
\end{tabular}

The Cash Conversion Cycle for "DELTA" is negative which is due to the company's size and position in the market as it provides it with the negotiating power to demand payments from clients to be liquidated in a short period of time whilst it can delay payments to suppliers.

\subsection{Estimate of z-scores and cash conversion cycle for "TRIKKI"}

The same Altman Z-score models were applied in order to estimate the Z-scores of "TRIKKI", a local company established initially as a cooperative firm in Trikala, Thessaly in 1960 by the Agricultural Bank of Greece and the Union of Bovine Breeders of Western Thessaly. In 2012 the firm assumed its operation as a cooperative one and was reestablished as a shared association following the provisions of articles 6 and 19 of Law No 4015/2011. The share capital of the firm amounts to $768.167,40 €$ comprising of 10,010 pieces of registered shares each one

${ }^{4}$ Calculations derived by the authors 


\section{Articles}

of which has a book value of $76.74 €$ (Milk Industry TRIKI, 2018). In order to define the variables comprising the Z-score components, we derived the data from the "TRIKKI" balance sheets and income statements of the years 2012, 2013, 2014, 2015 and 2016 as published by the firm on the internet. The data used are presented in Table 9 as follows:

Table 9: Data derived from "TRIKKI" financial statements for the estimate of the Z-score components

\begin{tabular}{|l|l|l|l|l|l|}
\hline Z-score components & $\mathbf{2 0 1 2}$ & $\mathbf{2 0 1 3}$ & $\mathbf{2 0 1 4}$ & $\mathbf{2 0 1 5}$ & $\mathbf{2 0 1 6}$ \\
\hline Current Assets & $10,687,461.36$ & $12,535,787.77$ & $12,599,935.61$ & $10,689,119.06$ & $14,196,344.43$ \\
\hline Current liabilities & $6,363,138.41$ & $7,903,699.73$ & $7,140,791.26$ & $7,039,089.78$ & $11,234,841.66$ \\
\hline Working Capital & $4,324,322.95$ & $4,632,088.04$ & $5,459,144.35$ & $3,650,029.28$ & $2,961,502.77$ \\
\hline Total Assets & $16,559,537.65$ & $19,073,275.91$ & $19,007,881.04$ & $17,656,417.09$ & $20,856,586.85$ \\
\hline Retained Earnings & $1,457,991.75$ & $1,736,624.55$ & $1,239,772.48$ & $2,425,832.71$ & $2,278,879.12$ \\
\hline EBIT & $291,316.93$ & $1,419,697.18$ & $1,385,551.31$ & $569,545.29$ & $308,708.88$ \\
\hline Sales & $17,330,571.84$ & $18,619,813.30$ & $20,503,947.78$ & $19,130,820.23$ & $19,714,634.51$ \\
\hline Book value of Equity & $6,354,876.68$ & $6,866,754.57$ & $6,336,509.40$ & $7,508,729.91$ & $7,512,512.22$ \\
\hline Total liabilities & $10,204,660.97$ & $12,206,521.74$ & $11,120,398.30$ & $10,147,687.18$ & $13,344,074.63$ \\
\hline
\end{tabular}

After applying the Altman (1983) Z-score model for non-publicly traded companies (Equation 2) and the Altman (2000) Z-score model for non-manufacturing companies and emerging markets (Equation 4), using the data of Table 5, we get the following Z-score values for "TRIKKI", presented in Table 10:

Table 10: "TRIKKI" Z'-score estimates for the years 2012 - 2016 using the Altman (1983) model for non-publicly traded firms and the Altman (2000) model for non-manufacturing firms or for emerging markets

\begin{tabular}{|c|c|c|c|c|c|}
\hline$Z^{\prime}$-score parameters & 2012 & 2013 & 2014 & 2015 & 2016 \\
\hline Z'-score (1983) & 1.622 & 1.693 & 1.804 & 1.757 & 1.42 \\
\hline$Z^{\prime \prime}$-score (2000) & 6.054 (BBB) & $6.264(\mathrm{BBB}+)$ & 6.458 (A-) & 6.097 (BBB) & $5.268(\mathrm{BB}+)$ \\
\hline
\end{tabular}

"TRIKKI" shows a relatively stable operation presenting $Z^{\prime}$-scores in the grey area between the bankruptcy and safety thresholds, i.e 1.23 and 2.9 respectively. Between 2012 and 2016 the firm keeps expanding as its total assets increase whilst at the same time it keeps its sales stable with an increasing tendency and its profits decreasing. In this case there could be a problem in liquidity, either mismanagement of its receivables and payables or too many expenses. The application of the Altman (2000) emerging markets model shows that "TRIKKI" performs satisfactorily taking into account the effect of the economic crisis.

The financial data for "TRIKKI" as they were retrieved from the company's financial statements and elaborated in order to estimate the Cash Conversion Cycle are presented in Table 11.

Table 11: "TRIKKI" financial data for the Cash Conversion Cycle estimate

\begin{tabular}{|l|l|l|l|l|l|}
\hline & $\mathbf{2 0 1 2}$ & $\mathbf{2 0 1 3}$ & $\mathbf{2 0 1 4}$ & $\mathbf{2 0 1 5}$ & $\mathbf{2 0 1 6}$ \\
\hline Cash & $244,764.59$ & $759,313.22$ & $119,165.29$ & $164,215.73$ & $168,726.87$ \\
\hline Securities & $33,662.05$ & $37,953.03$ & $101,371.16$ & $326,150.41$ & $435,623.61$ \\
\hline Receivables & $8,448,202.71$ & $9,535,387.85$ & $9,986,616.47$ & $8,405,207.27$ & $10,656,427.5$ \\
\hline
\end{tabular}




\begin{tabular}{|l|l|l|l|l|l|}
\hline & $\mathbf{2 0 1 2}$ & $\mathbf{2 0 1 3}$ & $\mathbf{2 0 1 4}$ & $\mathbf{2 0 1 5}$ & $\mathbf{2 0 1 6}$ \\
\hline TOTAL REC & $8,481,864.76$ & $9,573,340.88$ & $10,087,987.6$ & $8,731,357.68$ & $11,092,051.1$ \\
\hline Inventory & $1,960,832.01$ & $2,203,133.67$ & $2,392,782.69$ & $1,793,545.65$ & $2,935,566.45$ \\
\hline Sales & $17,330,571.8$ & $18,619,813.3$ & $20,503,947.8$ & $19,130,820.2$ & $19,714,634.5$ \\
\hline Cost of goods sold & $14,008,455.6$ & $13,930,745.0$ & $15,292,033.9$ & $14,384,170.2$ & $15,469,074.1$ \\
\hline average receivables & $8,481,864.76$ & $9,027,602.82$ & $9,830,664.26$ & $9,409,672.66$ & $9,911,704.40$ \\
\hline average inventory & $1,960,832.01$ & $2,081,982.84$ & $2,297,958.18$ & $2,093,164.17$ & $2,364,556.05$ \\
\hline CL & $6,363,138.41$ & $7,903,699,73$ & $7,140,791,26$ & $7,039,089,78$ & $11,234,841,66$ \\
\hline average CL & $6,363,138.41$ & $7,133,419,07$ & $7,522,245,50$ & $7,089,940,52$ & $9,136,965,72$ \\
\hline CGS & $14,008,455.7$ & $13,930,745,1$ & $15,292,033,9$ & $14,384,170,29$ & $15,469,074,2$ \\
\hline Expenses & $3,059,317,91$ & $3,300,909,99$ & $5,834,466.01$ & $4,650,035,16$ & 3788075,46 \\
\hline Interest & $641,740,75$ & $724,730,40$ & $261,722,01$ & $454,895,02$ & $373,653.93$ \\
\hline Depreciation & $1,044,085,75$ & $675,460,56$ & $723,192,33$ & - & $190,262.23$ \\
\hline $\mathbf{X}$ & $16,665,428,5$ & $17,280,924,8$ & $20,665,029,6$ & $19,489,100,4$ & $19,440,541.3$ \\
\hline
\end{tabular}

In Table 12 two estimates of the Cash Conversion Cycle are attempted, CCC (1) using the ending values of Accounts Receivable, Inventory and Current Liabilities and CCC (2) using the average values of the aforementioned magnitudes at the beginning and the end of the accounting year.

Table 12: Estimates of the cash conversion cycle using the ending values and the average values at the beginning and end of the accounting period for "TRIKKI"

\begin{tabular}{|l|l|l|l|l|l|}
\hline & 2012 & 2013 & 2014 & 2015 & 2016 \\
\hline TR_CCC(1) & 89 & 77 & 109 & 79 & 63 \\
\hline TR_CCC(2) & 89 & 80 & 96 & 98 & 67 \\
\hline
\end{tabular}

\section{DESCRIPTION OF RESULTS}

\subsection{Comparative Evaluation Of Estimated Z-Scores}

The performance of the dairy firms "THESS GALA PIES", a newly founded, innovative dairy firm, "DELTA", the fresh milk market leader and "TRIKKI", a local company with similar sales size to "THESS GALA PIES" is comparatively evaluated. The Altman (1983) model for non-public firms $Z^{\prime}$-score estimates of the aforementioned entities are presented in Table 13, below:

Table 13: Altman (1983) model for non - public firms $Z$ '-score estimates for the companies "THESS GALA PIES", "DELTA", "TRIKKI" and the Dairy Industry

\begin{tabular}{|l|l|l|l|l|l|l|}
\hline YEAR & 2011 & 2012 & 2013 & 2014 & 2015 & 2016 \\
\hline THESS GALA PIES & & 10.329 & 4.751 & 4.668 & 3.274 & \\
\hline DELTA & & 0.381 & 0.122 & 0.226 & 0.163 & 0.032 \\
\hline TRIKKI & & 1.622 & 1.693 & 1.804 & 1.757 & 1.42 \\
\hline
\end{tabular}

\footnotetext{
${ }^{5}$ Calculations derived by the authors
} 


\section{Articles}

The data of Table 13 above are plotted in Chart 1 below.

\section{Z-SCORES USING THE NON PUBLIC FIRMS MODEL}

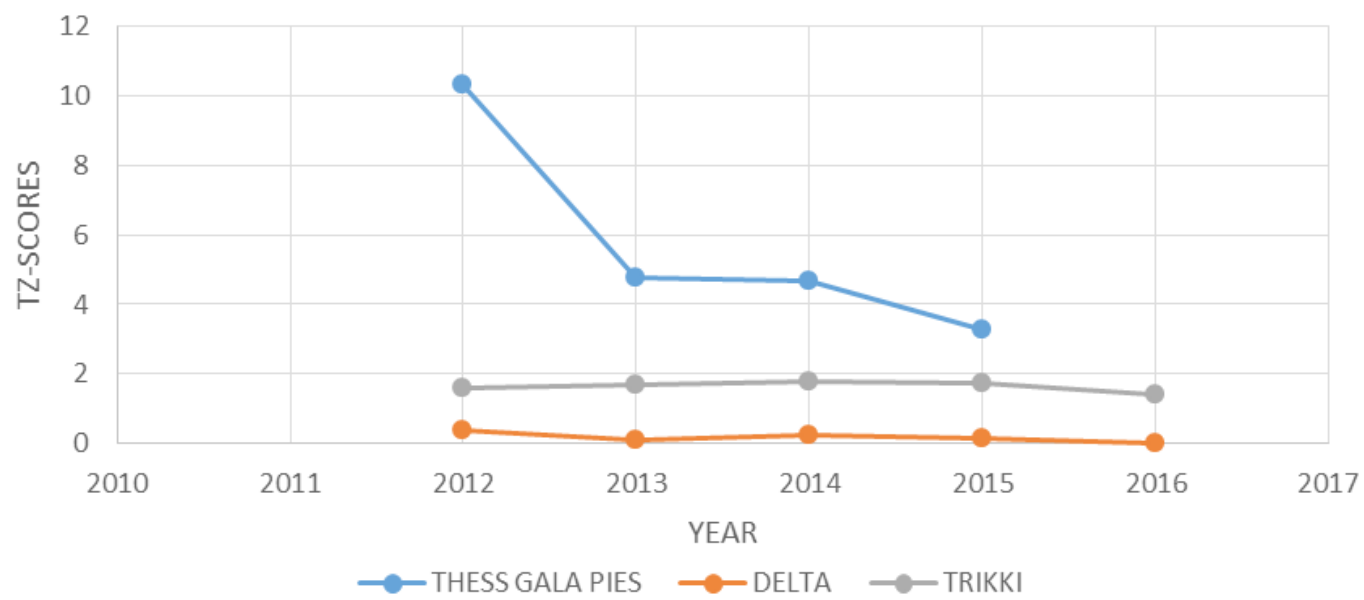

Chart 1: Altman (1983) model Z'-score estimates plotted against time

The graphic depiction of the aforementioned data shows that the dairy industry averages the rest as it was expected to be. The fresh milk market leader "DELTA" presents the lowest scores, whilst
"TRIKKI" and "THESS GALA PIES" present considerably higher scores.

The Altman (2000) model for emerging markets Z"'score estimates of the aforementioned entities are presented in Table 14, below:

Table 14: Altman (2000) model for emerging markets $Z^{\prime \prime}$-score estimates for the companies "THESS GALA PIES", "DELTA", "TRIKKI" and the Dairy Industry6

\begin{tabular}{|l|l|l|l|l|l|l|}
\hline YEAR & 2011 & 2012 & 2013 & 2014 & 2015 & 2016 \\
\hline THESS GALA PIES & & $5.759(\mathrm{BBB}-)$ & $5.583(\mathrm{BBB}-)$ & $4.395(\mathrm{~B})$ & $2.869(\mathrm{CCC})$ & \\
\hline DELTA & & $1.439(\mathrm{CCC}-)$ & $0.023(\mathrm{D})$ & $0.167(\mathrm{D})$ & $-0.171(\mathrm{D})$ & $-0.597(\mathrm{D})$ \\
\hline TRIKKI & & $6.054(\mathrm{BBB})$ & $6.264(\mathrm{BBB}+)$ & $6.458(\mathrm{~A}-)$ & $6.097(\mathrm{BBB})$ & $5.268(\mathrm{BB}+)$ \\
\hline
\end{tabular}

The data of Table 14 above are plotted in Chart 2 below.

Chart 2 presents almost the same image regarding the state of the entities compared. The fresh milk market leader "DELTA" performs below the other two dairy firms whilst "TRIKKI" seems to be performing better than all. As the sales component is omitted in the emerging markets model, the $Z^{\prime \prime}$-score estimates depict the management decisions concerning the use of the companies' assets and liabilities in the financing of their operations.

${ }^{6}$ Calculations derived by the authors 


\section{Z-SCORES USING THE EMERGING MARKETS MODEL}

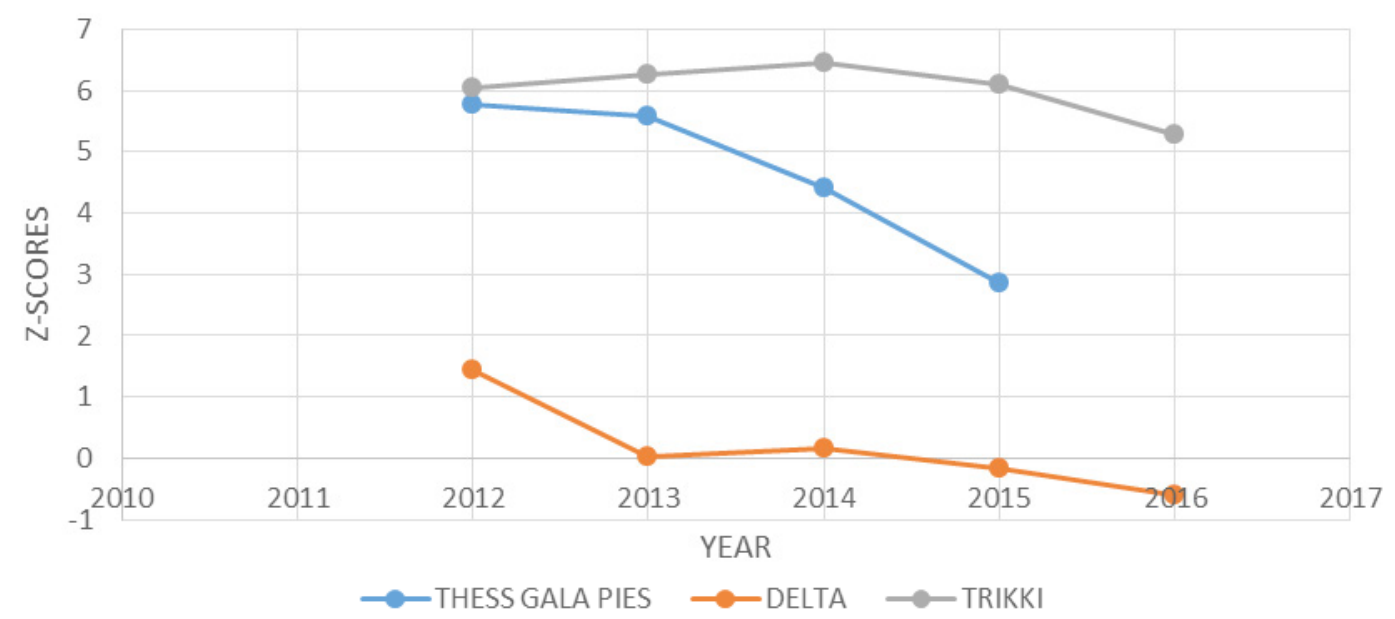

Chart 2: Altman (2000) model Z"'-score estimates plotted against time

4.2. Cash Conversion Cycle v/s Z-Score

\subsection{1. "THESS GALA PIES"}

The data of "THESS GALA PIES" Cash Conversion Cycle and the estimated Z-scores using the non - public firms model ( $Z^{\prime}$-SCORE (1)) and the emerging markets model ( $Z^{\prime \prime}$ SCORE (2)) are presented in Table 15, below:

Table 15: "THESS GALA PIES" Cash Conversion Cycle vs estimated Z-scores"

\begin{tabular}{|l|l|l|l|l|l|l|}
\hline YEAR & CCC(1) & Z'-SCORE(1) & Z''-SCORE(2) & CCC(2) & Z'-SCORE(1) & Z''-SCORE(2) \\
\hline 2012 & 3 & 10.329 & 5.759 & 3 & 10.329 & 5.759 \\
\hline 2013 & 13 & 4.751 & 5.583 & 7 & 4.751 & 5.583 \\
\hline 2014 & 3 & 4.668 & 4.395 & 10 & 4.668 & 4.395 \\
\hline 2015 & -26 & 3.274 & 2.869 & -15 & 3.274 & 2.869 \\
\hline
\end{tabular}

The correlation coefficients for the various regression analysis are presented in Table 16:

Table 16: Correlation coefficients of the regression analysis performed between CCC and Z-score ${ }^{8}$

\begin{tabular}{|l|l|l|}
\hline $\begin{array}{l}\text { Linear regression } \\
\text { analysis }\end{array}$ & Z-SCORE 1 & Z-SCORE 2 \\
\hline $\operatorname{CCC}(1)$ & 0.39 & 0.91 \\
\hline $\operatorname{CCC}(2)$ & 0.31 & 0.76 \\
\hline
\end{tabular}

As it can be observed from Table 16 above, there is a higher association between the two sets of data when the Z-score derived using the emerging markets model. The reason is because the Z- score derived by the application of the non-public firms model presents a very high value for the year 2012 almost equal to 10 which is obviously out of range compared to the Z-scores of the following years, hence

\footnotetext{
${ }^{7}$ Calculations derived by the authors

${ }^{8}$ Calculations derived by the authors
} 


\section{Articles}

affecting the relationship between the two sets of data.

The regression equations derived by the analysis above are:

Z-SCORE1 $=5.88+0.073 * \operatorname{CCC}(1) \quad$ (regression 1$)$

$\mathrm{Z}-\mathrm{SCORE} 2=4.78+0.072 * \operatorname{CCC}(1) \quad$ (regression 2$)$

Z-SCORE1 $=5.65+0.088 * \operatorname{CCC}(2) \quad($ regression 3$)$

Z-SCORE2 $=4.54+0.091 *$ CCC(2) (regression 4)

In order to define if a linear relationship between the two sets of data exists, we performed a hypothesis testing where the null hypothesis $\mathrm{HO}$ assumed that there is no linear relationship between the two sets of data and consequently the regression coefficient b1 equals 0 . The alternative hypothesis $\mathrm{H} 1$ assumed that a linear relationship between the two sets of data exists and consequently b1 is different to zero:

\section{Null hypothesis H0: b1 = $\mathbf{0}$}

\section{Alternative hypothesis H1: b1 $\neq 0$}

We performed a two-sided hypothesis testing using the t-distribution as the population variance is unknown according to Kavussanos (2005) because, as it has been mentioned, we do not have the data of the financial statements of the years 2016 and 2017 as the firm did not publish them. As we have already performed a regression analysis using the MS Office EXCELL, the results of the analysis were used in order to perform the hypothesis testing.

The degrees of freedom are $v=4-2=2$

The estimated value of $t$ is given by the following equation:

$t_{2}=\frac{b_{1}-\beta_{1}}{s e_{b_{1}}}$

Where:

b1 = the CCC regression coefficient

$\beta 1=0=$ the test value
$\mathrm{SE}_{\mathrm{b} 1}=$ the standard error of the regression coefficient as it resulted from the regression analysis

The value of $t$ critical is derived by the t- distribution curve for 2 degrees of freedom and $1-\alpha / 2=0,025$ according to Curwin, Slater and Eadson (2002). Hence the value of $t$ critical is:

$$
t_{2,0.025}=4,303
$$

The values of $t_{2}$ for all four regressions along with the regression coefficients, the correlation coefficients and the coefficients of determination are summarized in Table 17:

Table 17: $t$-tests for the coefficients of regressions 1 , 2, 3 and $4^{9}$

\begin{tabular}{|l|l|l|l|l|l|}
\hline & $\mathrm{r}$ & $\mathrm{r} 2$ & $\mathrm{~b} 1$ & $\mathrm{SEb} 1$ & $\mathrm{t} 2$ \\
\hline Regression 1 & 0.39 & 0.15 & 0.077 & 0.121 & 0.64 \\
\hline Regression 2 & 0.91 & 0.82 & 0.077 & 0.024 & 3.21 \\
\hline Regression 3 & 0.31 & 0.1 & 0.088 & 0.188 & 0.47 \\
\hline Regression 4 & 0.76 & 0.58 & 0.091 & 0.055 & 1.66 \\
\hline
\end{tabular}

As $t_{2}<t_{2,0.025}$ for all four regressions we cannot reject the null hypothesis $\mathrm{HO}$ according to which $\mathbf{b} \mathbf{1}=\mathbf{0}$ and cannot accept the alternative hypothesis $\mathrm{H} 1$ and hence there is strong evidence that a linear relationship does not seem possible to exist between the two sets of data, i.e. the cash conversion cycle VS the Z-scores derived by both the Altman (1983) model (regressions 1 and 3) and the Altman (2000) model (regressions2 and 4). Not rejecting the null hypothesis is also supported by the lower and upper limits of the CCC regression coefficients, all of which contain zero.

It is evident though that a relationship does exist between the two sets of data and specifically between the cash conversion cycle and the Z-score derived using the emerging markets model. Regressions 2

\footnotetext{
${ }^{9}$ Calculations derived by the authors
} 


\section{Articles}

and 4 present a high association between the aforementioned sets of data as $r_{\text {reg2 }}=$ 0,91 and $r_{\text {reg } 4}=0,76$, whilst in regression 2 the cash conversion cycle determines the Z-score by $82 \%$ and in regression 4 the cash conversion cycle determines the Z-score by $58 \%$. The adjusted determination coefficients of regressions 2 and 4 are 0.73 and 0.36 respectively. Between the two regression models we further investigate the regression 2 as it yielded a higher adjusted determination coefficient, which is an unbiased value and proclaims regression 2 as more reliable than regression 4 according to Curwin, Slater and Eadson( 2002).

We further investigate the linearity probability of regression 2 by applying a onesided hypothesis testing according to which:

\section{Null hypothesis H0: b1 = 0}

\section{Alternative hypothesis H1: b1 > 0}

The value of $t$ critical is derived by the $t-$ distribution curve for 2 degrees of freedom and $1-\alpha=0,05)$ as above. Hence the value of t critical is:

$$
t_{2,0.05}=2.920
$$

In this case and by comparing the $t_{2}$ value for regression 2 shown in Table 4.11 with $t_{2,0.05}$ we have:

$$
t_{2}>t_{2,0.05} \leftrightarrow 3.21>2.920
$$

Hence, there is evidence to reject the null hypothesis $\mathrm{HO}$ and accept the alternative hypothesis $\mathrm{H} 1$ according to which there is a positive linear relationship between the Cash Conversion Cycle and the Z-score derived by the Altman (2000) model. The relationship between the two variables is:

\section{Z-SCORE2 $=4.78+0.072 *$ CCC (1) (regression 2)}

Interpreting regression 2 we conclude that an increase by one (-01-) day of the Cash Conversion Cycle leads to an increase
The Effect of the Cash Conversion Cycle on the Z-scores of Fresh Milk Companies in Greece

of the Z-score by 0.072 units. Theoretically an increase of the CCC by 100 days would lead to an increase of the Z-score by 7 units. However, the increase of the Cash Conversion Cycle shows that a firm converts its receivables into cash more slowly as the liabilities term is subtracted, according to the Cash Conversion Cycle equation, as shown below:

$\mathrm{CCC}=360 *$ (AR/Sales $)+$

$$
+360 * \text { (Inventory/CGS) }-360 * \text { (CL/X) }
$$

The increase of Z-score implies an improvement of the financial health of a company, however the increase of the cash conversion cycle does not imply an improvement of the financial health as the company delays the liquidation of its receivables.

The $\mathrm{p}$ - values of the intercept 4.78 is $0.005<0.05$ whilst the $p-$ value for the CCC (1) regression coefficient is $0.09>0.05$. At a significance level of $5 \%$ there is strong evidence that the CCC (1) regression coefficient is not a significant predictor of the Z-score.

Summarizing all of the above and after investigating the probability of a linear relationship existing between the Cash Conversion Cycle and the Z-score we conclude that although a statistical correlation exists between the two sets of data, the regression equation does not describe in a meaningful manner the cause and effect relationship that exists between the two variables.

\subsection{2. "DELTA"}

The data of "DELTA" Cash Conversion Cycle and the estimated Z-scores using the non-public firms model ( $Z^{\prime}$-SCORE (1)) and the emerging markets model ( $Z^{\prime \prime}$-SCORE(2)) are presented in Table 18 below: 


\section{Articles}

Table 18: "DELTA" Cash Conversion Cycle vs estimated Z-scores ${ }^{10}$

\begin{tabular}{|l|l|l|l|l|l|l|}
\hline YEAR & CCC(1) & $Z^{\prime}$-SCORE(1) & $Z^{\prime \prime}$-SCORE(2) & CCC(2) & $Z^{\prime}$-SCORE(1) & Z' '-SCORE(2) $^{\prime}$ \\
\hline 2012 & -69 & 0.381 & 1.439 & -69 & 0.381 & 1.439 \\
\hline 2013 & -81 & 0.122 & 0.023 & -77 & 0.122 & 0.023 \\
\hline 2014 & -105 & 0.226 & 0.167 & -94 & 0.226 & 0.167 \\
\hline 2015 & -135 & 0.163 & -0.171 & -132 & 0.163 & -0.171 \\
\hline 2016 & -136 & 0.032 & -0.597 & -135 & 0.032 & -0.597 \\
\hline
\end{tabular}

The correlation coefficients for the various regression analysis are presented in Table 19:

Table 19: Correlation coefficients of the regression analysis performed between CCC and Z-score for "DELTA"

\begin{tabular}{|l|l|l|}
\hline $\begin{array}{l}\text { Linear regression } \\
\text { analysis }\end{array}$ & Z'-SCORE 1 & Z''-SCORE 2 \\
\hline D_CCC(1) & 0.687 & 0.816 \\
\hline D_CCC(2) & 0.683 & 0.786 \\
\hline
\end{tabular}

As it can be observed from Table 19 above, there is a higher association between the two sets of data when the Z-score derived using the emerging markets model is used.

The regression equations derived by the analysis above are:

DELTA_Z'-SCORE1 $=0.493+0.003 *$ CCC (1)

(regression 1)

DELTA_Z"'-SCORE2 $=2.319+0.02 *$ CCC (1)

(regression 2)

DELTA_Z'-SCORE1 $=0.479+0.003 *$ CCC (2)

(regression 3)

DELTA_Z"'-SCORE2 $=2.156+0.02 *$ CCC (2)

(regression 4)

In order to define if a linear relationship between the two sets of data exists we performed a hypothesis testing where the null hypothesis $\mathrm{HO}$ assumed that there is no linear relationship between the two sets of data and consequently the regression coefficient b1 equals 0 . The alternative hypothesis $\mathrm{H} 1$ assumed that a linear relationship between the two sets of data exists and consequently b1 is different to zero.

Null hypothesis H0: b1 = 0

Alternative hypothesis $\mathrm{H} \mathbf{1}: \mathbf{b} \mathbf{1} \neq \mathbf{0}$

We performed a two-sided hypothesis testing using the t-distribution as the population variance is unknown based on Kavussanos (2005) because, as it has been mentioned, we do not have the data of the financial statements of the total population, i.e. the financial data of the firm since its establishment. As we have already performed a regression analysis using the MS Office EXCELL, the results of the analysis were used in order to perform the hypothesis testing.

The degrees of freedom are $v=5-2=3$

The estimated value of $t$ is given by equation 6 , as follows:

$$
t_{2}=\frac{b_{1}-\beta_{1}}{s e_{b_{1}}}
$$

Where:

b1 = the CCC regression coefficient

$\beta 1=0=$ the test value

$\mathrm{SE}_{\mathrm{b} 1}=$ the standard error of the regression coefficient as it resulted from the regression analysis

The value of $t$ critical is derived by the t- distribution curve for 3 degrees of freedom and $1-\alpha / 2=0,025$ based on Curwin, Slater and Eadson (2002). Hence the value of $t_{\text {crit }}$ is:

$$
t_{3,0.025}=3.182
$$

${ }^{10}$ Calculations derived by the authors 


\section{Articles}

The values of $t_{3}$ for all four regressions along with the regression coefficients, the
The Effect of the Cash Conversion Cycle on the Z-scores of Fresh Milk Companies in Greece

Table 20: $t$-testing for the regression coefficients

\begin{tabular}{|l|l|l|l|l|l|}
\hline & $\mathrm{R}$ & $\mathrm{r}^{2}$ & $\mathrm{~b} 1$ & $\mathrm{~S} E \mathrm{l} 1$ & $\mathrm{t}_{3}$ \\
\hline Regression 1 & 0.687 & 0.472 & 0.003 & 0.0018 & 1.667 \\
\hline Regression 2 & 0.816 & 0.665 & 0.02 & 0.0084 & 2.381 \\
\hline Regression 3 & 0.683 & 0.467 & 0.003 & 0.0018 & 1.667 \\
\hline Regression 4 & 0.786 & 0.618 & 0.02 & 0.0089 & 2.247 \\
\hline
\end{tabular}

As $t_{3}<t_{3,0.025}$ for all four regressions we should accept the null hypothesis $\mathrm{HO}$ according to which $\mathbf{b} \mathbf{1 = 0}$ and reject the alternative hypothesis $\mathrm{H} 1$ and hence a linear relationship does not seem probable to exist between the two sets of data, i.e. the cash conversion cycle VS the Z-scores for "DELTA". It is evident though that a relationship does exist between the two sets of data and specifically between the cash conversion cycle and the $Z^{\prime \prime}$-score derived using the Altman (2000) emerging markets model. Although Regressions 2 and 4 present a high association between the aforementioned sets of data as $r_{\text {reg2 }}=0.816$ and $r_{\text {reg } 4}=0.786$, the p- values of the CCC (1) and CCC (2) independent variables in both cases are equal to 0.09 and 0.12 respectively, hence being a lot higher than the level of significance $\alpha=0.05$ and consequently statistically non-significant.

In the hypothetical case that the level of significance $\alpha=0.10$, then Regression 2 states a linear relationship between the Cash Conversion Cycle and the Z"'-score. Nevertheless, the interpretation of Regression 2 states that for an increase of the CCC by correlation coefficients and the coefficients of determination are summarized in Table 20:

Table 21: "TRIKKI" Cash Conversion Cycle vs estimated Z-scores"

\begin{tabular}{|l|l|l|l|l|l|l|}
\hline YEAR & TR_CCC(1) & Z'-SCORE(1) & Z''-SCORE(2) & TR_CCC(2) & Z'-SCORE(1) & Z''-SCORE(2) \\
\hline $\mathbf{2 0 1 2}$ & 89 & 1.622 & 6.054 & 89 & 1.622 & 6.054 \\
\hline $\mathbf{2 0 1 3}$ & $\mathbf{7 7}$ & 1.693 & 6.264 & 80 & 1.693 & 6.264 \\
\hline $\mathbf{2 0 1 4}$ & 109 & 1.804 & 6.458 & 96 & 1.804 & 6.458 \\
\hline
\end{tabular}

${ }^{11}$ Calculations derived by the authors

one (-01-) day, the $Z^{\prime \prime}$-score increases by 0.02 units. Theoretically an increase of the CCC by 100 days would lead to an increase of the Z-score by 2 units. However, the increase of the Cash Conversion Cycle shows that a firm converts its receivables into cash more slowly.

Summarizing all of the above and after investigating the probability of a linear relationship existing between the Cash Conversion Cycle and the Z-score, we conclude that although a statistical correlation exists between the two sets of data, the regression equation does not describe in a meaningful manner the cause and effect relationship that exists between the two variables. At a significance level of $5 \%$ there is strong evidence that the CCC (1) regression coefficient is not a significant predictor of the Z-score as 0.09>0.05.

\subsection{3. "TRIKKI"}

The data of "TRIKKI" Cash Conversion Cycle and the estimated Z-scores using the non- public firms model ( $Z^{\prime}$-SCORE (1)) and the emerging markets model ( $Z^{\prime \prime}$-SCORE(2)) are presented in Table 21 , below: 


\begin{tabular}{|l|l|l|l|l|l|l|}
\hline YEAR & TR_CCC(1) & Z'-SCORE(1) & $Z^{\prime \prime}$-SCORE(2) & TR_CCC(2) & $Z^{\prime}$-SCORE(1) & Z''-SCORE(2) \\
\hline 2015 & 79 & 1.757 & 6.097 & 98 & 1.757 & 6.097 \\
\hline 2016 & 63 & 1.42 & 5.268 & 67 & 1.42 & 5.268 \\
\hline
\end{tabular}

The correlation coefficients for the various regression analysis for "TRIKKI" are presented in Table 22

Table 22: Correlation coefficients of the regression analysis performed between CCC and Z- score for "TRIKKI"

\begin{tabular}{|l|l|l|}
\hline $\begin{array}{l}\text { Linear regression } \\
\text { analysis }\end{array}$ & Z'-SCORE 1 & Z''-SCORE 2 \\
\hline TR_CCC(1) & 0.754 & 0.802 \\
\hline TR_CCC(2) & 0.894 & 0.788 \\
\hline
\end{tabular}

As it can be observed from Table 22 above, there is a higher association between the two sets of data when the Z-score derived using the emerging markets model is used.

The regression equations derived by the analysis above are:

TRIKKI_Z'-SCORE1 $=1.105+0.007 *$ CCC (1)

(regression 1)

TRIKKI_Z"'-SCORE2 $=4.247+0.02 *$ CCC (1)

(regression 2)

TRIKKI_Z'-SCORE1 $=0.753+0.01^{*}$ CCC (2)

(regression 3)

TRIKKI_Z"'-SCORE2 $=3.616+0.03 *$ CCC (2)

(regression 4)

In order to define if a linear relationship between the two sets of data exists we performed a hypothesis testing where the null hypothesis $\mathrm{HO}$ assumed that there is no linear relationship between the two sets of data and consequently the regression coefficient b1 equals 0 . The alternative hypothesis $\mathrm{H} 1$ assumed that a linear relationship between the two sets of data exists and consequently b1 is different to zero.
Null hypothesis H0: b1 = 0

\section{Alternative hypothesis $\mathrm{H} 1$ : $\mathbf{b} 1 \neq 0$}

We performed a two-sided hypothesis testing using the $\mathrm{t}-$ distribution as the population variance is unknown according to Kavussanos (2005) because, as it has been mentioned before, we do not have the data of the financial statements of the total population, i.e. the financial data of the firm since its establishment. As we have already performed a regression analysis using the MS Office EXCELL, the results of the analysis were used in order to perform the hypothesis testing.

The degrees of freedom are $v=5-2=3$

The estimated value of $t$ is given by equation 6 , as follows:

$$
t_{2}=\frac{b_{1}-\beta_{1}}{s b_{b_{1}}}
$$

Where:

b1 = the CCC regression coefficient

$\beta 1=0=$ the test value

$\mathrm{SE}_{\mathrm{b} 1}=$ the standard error of the regression coefficient as it resulted from the regression analysis

The value of $t$ critical is derived by the t-distribution curve for 3 degrees of freedom and $1-\alpha / 2=0,025$ according to Curwin, Slater and Eadson (2002). Hence the value of $t$ crit is:

$$
t_{3,0.025}=3.182
$$

The values of $t_{3}$ for all four regressions along with the regression coefficients, the correlation coefficients and the coefficients of determination are summarized in Table 23: 
Table 23: $t$ - testing for the regression coefficients ${ }^{12}$

\begin{tabular}{|l|l|l|l|l|l|}
\hline & $\mathbf{r}$ & $\mathbf{r}^{2}$ & $\mathbf{b 1}$ & $\mathbf{S E b 1}$ & $\mathbf{t}_{3}$ \\
\hline Regression 1 & 0.754 & 0.57 & 0.007 & 0.0033 & 2.12 \\
\hline Regression 2 & 0.802 & 0.644 & 0.02 & 0.0091 & 2.198 \\
\hline Regression 3 & 0.894 & 0.80 & 0.01 & 0.0030 & 3.333 \\
\hline Regression 4 & 0.788 & 0.621 & 0.03 & 0.013 & 2.31 \\
\hline
\end{tabular}

As $t_{3}<t_{3.0 .025}$ for the three regressions except for regression 3 , we should accept the null hypothesis $\mathrm{HO}$ according to which $\mathbf{b} \mathbf{1}=\mathbf{0}$ and reject the alternative hypothesis $\mathrm{H} 1$ and hence a linear relationship does not seem probable to exist between the two sets of data, i.e. the cash conversion cycle VS the Z-scores for "TRIKKI". It is evident though that a relationship does exist between the two sets of data and specifically between the cash conversion cycle and the Z-score derived using the Altman (2000) emerging markets model. Regressions 2 and 4 present a high association between the aforementioned sets of data as $r_{\text {reg2 }}=0.802$ and $r_{\text {reg4 }}=0.788$, the $p$ - values of the $\operatorname{CCC}(1)$ and $\operatorname{CCC}(2)$ independent variables in both cases are equal to 0.10 and 0.11 respectively, hence being a lot higher than the level of significance $a=$ 0.05 and consequently statistically non significant.

Regarding regression $3, t_{3}>t_{3.0 .025}$ as $3.33>3.182$ and hence we should reject the null hypothesis $\mathrm{HO}$ according to which b1 $\mathbf{0}$ and accept the alternative hypothesis $\mathrm{H} 1$ and hence a linear relationship does seem probable to exist between the two sets of data for "TRIKKI". A high association between the aforementioned sets of data exists as $r_{\text {reg } 3}=0.894$, whilst in regression 3 the cash conversion cycle determines the $Z$-score by $80.0 \%$. Moreover the $p$-value of the $\operatorname{CCC}(2)$ independent variable is equal to 0.04 , hence lower then $a=0.05$ and consequently being statistically significant. Regression 3 states that an increase of the Cash Conversion Cycle by one (-01-) day leads to an increase of the Z-score by 0.01 units. Theoretically an increase of the CCC by 100 days would lead to an increase of the Z-score by 1 unit. However, the increase of the Cash Conversion Cycle shows that a firm converts its receivables into cash more slowly.

Summarizing all of the above and after investigating the probability of a linear relationship existing between the Cash Conversion Cycle and the Z-score, we conclude that although a statistical correlation exists between the two sets of data, the regression equation does not describe in a meaningful manner the cause and effect relationship that exists between the two variables, although at a significance level of $5 \%$ there is strong evidence that the CCC(2) regression coefficient of Regression 3 is a significant predictor of the Z-score as $0.04<0.05$.

\section{CONCLUSIONS}

In this study, the effect of the Cash Conversion Cycle on the Z-scores of three selected Greek dairy firms was examined in order to investigate the impact of liquidity to the viability of selected firms operating in the dairy sector. A comparative analysis of the estimated Z-scores of the newly founded and innovative dairy firm "THESS GALA PIES" in

\footnotetext{
${ }^{12}$ Calculations derived by the authors
} 


\section{Articles}

relation to the respective ones of "DELTA", the fresh milk market leader and "TRIKKI", a local dairy firm of similar sales size to "THESS GALA PIES" initially took place. Concerning the Altman (1983) non-public firms model (Equation 2), "THESS GALA PIES" performs above the safety threshold, "TRIKKI" performs in the grey area whilst "DELTA" performs below the bankruptcy threshold. Concerning the Altman (2000) emerging markets model (Equation 4), which omits the sales parameter at the estimate of Z-score, "TRIKKI" shows the best performance with its scores being equivalent to bond rating above $\mathrm{BB}+$, "THESS GALA PIES" presents scores equivalent to bond rating below BBB-, whilst "DELTA" presents the lowest scores equivalent to $D$ bond rating.

The effect of the Cash Conversion Cycle on the Z-scores of both models was investigated for "THESS GALA PIES", "DELTA" and "TRIKKI". "THESS GALA PIES" presents a very low and positive Cash Conversion Cycle which is due to the fact that the period the company needs to convert its receivables and inventory into cash is slightly longer than the payment deferral period. "DELTA" presents a negative Cash Conversion Cycle as the firm manages to convert its receivables and inventory into cash earlier than paying off its liabilities. On the other hand, "TRIKKI" presents a positive Cash Conversion Cycle and needs from two (-2-) to three (-3-) months to convert its receivables and inventory into cash. The regression analysis of the effect of the Cash Conversion Cycle on the Z-scores of both models for "THESS GALA PIES", "DELTA" and "TRIKKI" showed that the two aforementioned sets of data are highly associated but the hypothesis of a linear relationship between them was rejected. It is noted that the data of financial statements of the years from 2012 to 2016 of the aforementioned entities were used in the present study. In the case of a greater sample, it is highly probable that the linearity between the Cash Conversion Cycle and the Z-scores would exist. Of course, we cannot generalize for the whole fresh milk industry based on a sample of three firms, but we can get a first impression of where it is heading, since we have examined the market leader, which is an international company and two significant local ones. We wanted to see how a new company, the "THESS GALA PIES", established during the crisis, with an innovative distribution way was doing with regard to its liquidity and viability and in comparison to the market's leader and to a similar traditional firm. The implications of our results are that, despite the heavy economic crisis, new companies can survive and grow and this is an optimistic message towards practitioners and policy makers alike.

The limitations and difficulties faced in this study were mainly associated to the limited amount of data as "THESS GALA PIES" is a relatively young company, which by itself constricted the study period of the research. The limited amount of data did not allow for the application of a multi-variable regression model, which would better investigate the effect of the Cash Conversion Cycle along with other financial indexes on the formation of Z-score. Future research could extend the present and investigate in depth the factors that affect the firm's viability of the dairy products sector in terms of other liquidity measures (the static ones), management efficiency, marketing efficiency, locality, size, etc.

As the dairy sector is of high importance to the Greek economy because it is associated with the primary sector and also has a strong exportation orientation, further study of the application of corporate financial distress prediction models should take place emphasizing the calibration of the revised Altman models in order to take into account the particularities of the Greek market and 


\section{Articles}

economy. Hence future research could include all the firms of the sector, and could focus on examining the z-score with some macroeconomic variables such as the annual GDP change rate, the unemployment rate, the interest rate, the inflation rate or the consumer price index. We could also extend this study for the whole European Union dairy sector as well as other sectors of the food industries for Greece and for EU and search for those factors that make for success in the member countries. It can be extended also for the US market and make comparisons between the EU and US dairy firms.

\section{REFERENCES}

Alipour, M., 2011. Working capital management and corporate profitability: Evidence from Iran. World applied sciences journal, 12(7), pp. 1093-1099.

ALKINOOS Publications, 2018, Greek Industry, Retrieved from and available on http://www.inr.gr [Accessed last 12 May 2018] (in Greek)

Altman, E. I. 1968, September, Financial Ratios, Discriminant Analysis and the Prediction of Corporate Bankruptcy, Journal of Finance, Vol 23 (No 4), pp. 589-603, [Online] [Accessed 21 January 2018] Available: https://pdfs.semanticscholar.org/cab5/059bfc5bf4b70b106434e0cb6 65f3183fd4a.pdf,.

Altman, E. I. 1983, Discussion, Journal of Finance, Vol 38 (No 2), pp. 517-522.

Altman, E. I. 2000, Predicting Financial Distress of Companies: Revisiting the Z-score and Zeta Models, [Online] [Accessed 21 January 2108]. available on http://pages.stern.nyu.edu/ ealtman/ Zscores.pdf,

Altman, E. I., \& Hotchkiss, E. 2006, Corporate Financial Distress and Bankruptcy: Predict and Avoid Bankruptcy, Analyze and Invest in Distressed Debt, New Jersey: John Wiley and Sons Inc, [Online] [Accessed 21 January 2018].
The Effect of the Cash Conversion Cycle on the Z-scores of Fresh Milk Companies in Greece

available on https://onlinelibrary.wiley.com/doi/ book/10.1002/9781118267806,

Altman, E. I., Iwanicz-Drozdowska, M., Laitinen, E. K., \& Suvas, A. 2014. Distressed Firm and Bankruptcy prediction in an international context: a review and empirical analysis of Altman's Z-Score Model, [Online] [Accessed 21 December 2107] . available: https://poseidon01.ssrn.com/delivery.php? ID $=502127090083071029024089113080091089$ 097086084036020059023087065071009112118 083026119033028006123050113058085071006 093103013017062005008023034102025096116 0290870021160210350851000870781210161180 670170931211081271 ,

Anser, Raheem, and Qaisar Ali Malik, 2013. Cash Conversion Cycle and Firms' ProfitabilityA Study of Listed Manufacturing Companies of Pakistan. Journal of Business and Management 8(2), pp. 82-87.

Apergis, N., Lyroudi, K., \& McCarty, D. 2007. The Role of Liquidity in Terms of Profitability and Indebtness: A Panel Cointegration and Causality Approach. Asian-African Journal of Economics and Econometrics, 7(1-2), pp. 1-19.

Arvanitidou, F., \& Anastasiadou, E. 2015, Financial Statements Analysis of the dairy company "NEOGAL S.A.", BSc thesis, Kavala: Technological Institute of Kavala, [Online] [Accessed 16 February 2018] (in Greek). available on http://digilib.teiemt.gr/jspui/bitstre am/123456789/580/1/022014075.pdf,

ATHEXGroup, 2017, company selection - helex. gr. Retrieved from and available on www.helex. $\mathrm{gr} / \mathrm{el} / \mathrm{web} / \mathrm{guest} / \mathrm{companies-map/-/}$ cmap/s/3577/2 [Accessed last 19 February 2018] (in Greek)

Belt, B., 1985. The Trend of the Cash Conversion Cycle and its Components. Akron Business and Economic Review, 16(3), pp. 48-54

Besley, Scott and R. L. Meyer, 1987. An Empirical Investigation of Factors Affecting the Cash Conversion Cycle, presented at the Annual 


\section{Articles}

Meeting of the Financial Management Association, Las Vegas, Nevada, October 1987.

Bindu, T. H., \& Subrahmanyam, S. E. 2012, December. A study on financial health of dairy industry in Andhra Pradesh based on Z score analysis. International Journal of Marketing, Financial Services \& Management Research, 1 (12), pp. 54-61, [Online] [Accessed 01 May 2018] . available: http://indianresearchjournals.com/ pdf/IJMFSMR/2012/December/4.pdf,

Bindu, T. H., Subrahmanyam, S. E., \& Bhat, M. S. 2015, April. Financial performance analysis of selected dairy units in Andhra Pradesh using Altman Z score model. Asia Pacific Journal of Research, I (XXVI), pp. 34-42, [Online] [Accessed 01 May 2018].available: http://apjor.com/ downloads/140520155.pdf,

Boda, M., \& Uradnicek, V. 2016, The portability of altman's Z-score model to predicting corporate financial distress of Slovak companies, Technological and Economic Development of Economy, 22 (4), pp. 532-553, [Online] .[Accessed 05 May 2018] available: https://journals.vgtu.It/index.php/TEDEarticle/download /737/546,

Businessnews 2018, 01, 19, Under authorized supervision the merging of DELTA - MEVGAL. Retrieved from and available [Accessed 07 March 2018] (In Greek) Businessnews: http:// www.businessnews.gr/article/97280/me-entolodoho-i-syghoneysi-delta-mevgal,

Charitou, M. S., Elfani, M., \& Lois, P., 2010. The effect of working capital management on firm's profitability: empirical evidence from an emerging market. Journal of Business \& Economics Research (JBER), 8(12).

Cristea, Chiprian and Cristea, Maria 2018. The Cash conversion cycle and Corporate Performance: Evidence from Romania. MATEC Web of Conferences 184, 04009 https://doi.org/10.1051/ matecconf/201818404009, Annual Session of Scientific Papers IMT ORADEA 2018
Dash, M., \& Ravipati, R., 2009. A liquidity-profitability trade-off model for working capital management. Available at SSRN 1408722.

Deloof, M., 2003. Does working capital management affect profitability of Belgian firms?. Journal of business finance \& Accounting, 30(3-4), pp. 573-588.

Dong, H. P. and J-T Su, 2010. The relationship between working capital management and profitability: a Vietnam case. International Research Journal of Finance and Economics 49(1), pp. 6271.

Dunkley, J. 2013, June 12. Greece becomes the first developed country to be downgraded to emerging market status. Retrieved from and available on Independent [Accessed 20 December 2017]: https://www.independent.co.uk/news/ business/news/greece-becomes-first-developed-country-to-be-downgraded-to-emergingmarket-status-8655730.html,

Ebben, J. J., \& Johnson, A. C.,2011. Cash conversion cycle management in small firms: Relationships with liquidity, invested capital, and firm performance. Journal of Small Business \& Entrepreneurship, 24(3), pp. 381-396.

El Khoury, R., \& Al Beaino, R. 2014. Classifying Manufacturing Firms in Lebanon: An Application of Altman's Model. Procedia - Social and Behavioral Sciences 109, pp. 11-18, [Online] [Accessed 06 May 2018], available: https://www.researchgate.net/publication/260007863_Classifying_ Manufacturing_Firms_in_Lebanon_An_Application_of_Altman's_Model/download,

Eriotis, N. 2005. Financial Statement Analysis. Patras: Hellenic Open University.

Farris T., M., \& Hutchison, P. D. 2002. Cash-tocash: the new supply chain management metric. International Journal of Physical Distribution \& Logistics Management, 32(4), pp. 288-298.

Filbeck, G., \& Krueger, T. M., 2005. An analysis of working capital management results across industries. American Journal of Business, 20(2), pp. $11-20$ 


\section{Articles}

Gallinger, George. 1997, The current and quick ratios: do they stand up to scrutiny?: Drop the current ratio-pick up the CCC. Business Credit 99(5), pp. 22-23.

Garanina, Tatiana and Olga Petrova, 2015. Liquidity, cash conversion cycle and financial performance: case of Russian companies. Investment Management and Financial Innovations, 12(1), pp. 90-100.

Garcia-Teruel, P.J. and Martinez-Solano, P., 2007. Effects of Working Capital Management on SME Profitability. International Journal of Managerial Finance. 3 (2), pp 164-177.

Gatomati, F. 2016, The impact of SMEs Z-score on their access to bank loans, MSc Dissertation in Applied Economics \& Data Analysis, School of business Administration Department of Economics, Patras: University of Patras, [Online], [Accessed 12 December 2017] (in Greek)available on http://nemertes.lis.upatras.gr/jspui/ bitstream/10889/9889/1/GatomatiThe\%20impact $\% 20$ of $\% 20$ SMEs $\% 20 Z$-score $\% 20$ on $\% 20$ their\%20access $\% 20$ to\%20bank\%20loans.pdf,

Gawali, R. B., \& Gadekar, A. 2017, December. Comparative Financial Health Analysis of Cooperative Milk Processing Plants in Ahmednagar District of Maharashtra. Journal of Business Management, 3 (12), pp. 107-114, [Online] [Accessed 05 May 2018] available: https://ijrdo.org/ index.php /bm/article/view/1744/1639,

Gentry, James A., R. Vaidyanathan and Hei Wee Lee, 1990. A Weighted Cash Conversion Cycle. Financial Management, pp. 90-99.

Gill, Amarjit, Nahum Biger, and Neil Mathur, 2010. The relationship between working capital management and profitability: evidence from The United States. Business and Economics Journal 10, pp. 1-9.

Gkokas, P., \& Praggdidis, I. 2010, Modern enterprise - Tools of entrepreneurial analysis. Athens: Dionikos Editions, (in Greek).

Grice, J. S., \& Ingram, R. W. 2001. Tests of the Generalizability of Altman's Bankruptcy Predic-
The Effect of the Cash Conversion Cycle on the Z-scores of Fresh Milk Companies in Greece

tion Model. Journal of business Research, 54, pp. 53-61, [Online] [Accessed 20 December 2017].available: https://www.sciencedirect.com/ science/article/abs/pii/S0148296300001260,

Grosse-Ruyken, Pan Theo, Stephan M. Wagner, and Ruben Jonke., 2011. What is the right cash conversion cycle for your supply chain? International Journal of Services and Operations Management 10(1), pp. 13-29.

Hager, H.C.1976, Cash Management and Cash Cycle. Management Accounting, pp. 19-21.

IBHS. 2017, November. The Greek Dairy / Cheese Market - Part A : Retrieved from and available on Dairy News[Accessed 20 December 2017], (in Greek): www.dairynews.gr/2017/11/04/

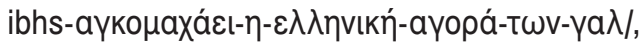

Jose, Manuel L., Lancaster Carol, Stevens J.L.,1996. Corporate Returns and Cash Conversion Cycles. Journal of Economics and Finance, 20 (1), pp 35-48.

Kamath, R.,1989. How Useful are Common Liquidity Measures? Journal of Cash Management., pp. 24-28.

Kaplinski, O. 2008, Usefulness and Credibility of Scoring Methods in Construction Industry. Journal of Civil Engineering and Management, 14(1), pp. 21-28, [Online] [Accessed 04 May 2018]. available: https://www.google.gr/url?sa=t\&rct=j\& $q=\&$ esrc $=$ s\&source $=$ web\& $c d=2 \& c a d=r j a \& u a c t=8$ \&ved=2ahUKEwjJ2I_m2L7hAhUjwMQBHRrbD9 kQFjABegQIAhAC\&url=https $\% 3 A \% 2 F \% 2 F j o u r n a$ Is.vgtu.It $\% 2$ Findex.php $\% 2 F J C E M \% 2 F a r t i c l e \% 2 F d$ ownload\%2F6813\%2F5887\%2F\&usg=AOvVaw2I 1z629iCKNMsB640HcLN1,

Kelenidou, K. 2015, October. Effects of mergers and acquisitions in the dairy industry in Greece. The case of "DODONI S.A.", MSc thesis for the aquisition of the MSc title in Strategic Accounting and Financial Management, ThessaIoniki, Greece: University of Macedonia, [Online] [Accessed 16 January 2018], (in Greek) available on https://dspace.lib.uom.gr/bit- 


\section{Articles}

stream/2159/18573/6/KelenidouKyriakiMsc2015. pdf,

Kral, P., Fleischer, M., Stachova, M., Nedelova, G., \& Sobisek, L. 2016. Corporate Financial Distress Prediction of Slovak COMPANIES: Z-score Models vs alternatives. 19th Applications of Mathematics and Statistics in Economics. Banska Stiavnica: AMSE, [Online] [Accessed 21 January 2018], available: www.amse.umb.sk/ proceedings/KralFleischerStachovaNedelovaSobisek.pdf,

Lyroudi, K. and McCarty, D.,1993. An Empirical Investigation of the Cash Conversion Cycle of Small Business Firms. Journal of Small Business Finance. Renamed as The Journal of entrepreneurial Finance, 2 (2), pp. 139-161.

Lyroudi, K., \& Lazaridis, Y., 2000. The cash conversion cycle and liquidity analysis of the food industry in Greece, EFMA 2000, Athens

Lyroudi, K., Rychter (Bolek), 2012. M. An investigation of the companies liquidity and the factors affecting it: The case of Poland. Multinational Finance Society Annual Conference, Kraków.

Manifava, D. 2017, October 20. The merging of MEVGAL - DELTA approved with asterisks. Retrieved from and available on Kathimerini [Accessed 07 March 2018] (in Greek): www.kathimerini.gr/931526/article/oikonomia/epixeirhseis/ egkri8hke-me-asteriskoys-h-sygkentrwsh-mevgal-delta,

Mantziaris, S. Z. 2015, October. Bankruptcy Prediction Models: An Empirical Analysis of Altman's Z - Score model in Forty Greek Companies in the Period of Economic Recession. MSc Dissertation in Accounting and Finance, School of Business Administration, Department of Accounting And Finance, Thessaloniki: University of Macedonia, [Online] [Accessed 20 January 2018] (in Greek)available on:https://dspace.lib. uom.gr/bitstream/2159/18618/6/MantziarisZapheirisStergiosMsc2015.pdf,

Mathuva, D.,2009, The influence of working capital management components on corporate prof- itability: a survey on Kenyan listed firms. Research. Journal of Business Management 3(1), pp. 1-11.

Meeampol, S., Lerskullawat, P., Wongsorntham, A., Srinammuang, P., Rodpetch, V., \& Noonoi, R. 2014. Applying Emerging Market Z-Score Model to Predict Bankruptcy: A Case Study of Listed Companies in the Stock Exchange of Thailand (Set). Management, Knowledge and Learning International Conference, (pp. 1227-1237). Partoroz, [Online] [Accessed 05 May 2018], available: http://www.toknowpress.net/ISBN/978-9616914-09-3/papers/ML14-724.pdf,

Mehmet, D. E. N., \& Eda, O. R. U. C., 2009. Relationship between efficiency level of working capital management and return on total assets in ISE (Istabul stock exchange). International journal of Business and Management, 4(10), p109.

Milk Industry TRIKI. 2018, Milk Industry TRIKI official webpage, Retrieved from and available on http://www.trikki.com.gr,

Moss, D.J. and B. Stine,1993. Cash Conversion Cycle and Firm Size: A Study of Retail Firms. Managerial Finance. 19 (8,K), pp. 25-34.

Mohamad, Nor Edi Azhar Binti, and Noriza Binti Mohd Saad., 2010. Working capital management: The effect of market valuation and profitability in Malaysia. International Journal of Business and Management 5(11): p140.

Nikolaidis, Alexis, 2017. IBHS: The Greek Dairy Market is in pain (in Greek), Dairy News, issue 7, June 2017. http://www.ibhs.gr/index.php/el/ourservices/kladikes-meletes/item/245-dairy-products,

Nobaneee, H. And AlHajjar, M., 2009a. Working Capital Management, Operating Cash Flow and Corporate Performance. SSRN Working Paper Series.http://ssrn.com/abstract=1471236, pages 12.

Nobaneee, H. And AlHajjar, M., 2009b. Optimizing Working Capital Management. SSRN, Work- 


\section{Articles}

ing Paper Series. http://ssrn.com/abstract=1528894, pages 21 .

Nobaneee, H. And AlHajjar, M., 2009c. A note on Working Capital Management and Corporate Profitability of Japanese Firms. SSRN Working Paper Series.http://ssrn.com/abstract=1433243, pages 9.

Nordgren, R.K.,1981. The Cornerstone of Liquidity Analysis: Working Capital. The Journal of Commercial Bank Lending., pp. 11-19.

Opler, Tim, et al., 1999. The determinants and implications of corporate cash holdings." Journal of financial economics 52(1), pp. 3-46.

Patanwala, A. 2016. A prediction of the financial distress of the major players in the FMCG sector using revised Altman Z-score model and liquidity ratios. Business Sciences International Research Journal, 4 (1), pp. 77-82, [Online] [Accessed 20 December 2017]available: http://imrfjournals.in/pdf/MATHS/BSIRJ-NEW-JOURNALS/ BSIRJ-41/14.pdf,

Phillips, M. 2013, June 11. Greece is becoming an emerging market. Retrieved from Quartz Media LLC: [Accessed 20 December 2017] https:// qz.com/93510/greece-is-becoming-an-emerging-market-country,

Raheman, Abdul, and Mohamed Nasr., 2007. Working capital management and profitabilitycase of Pakistani firms. International review of business research papers 3(1), pp. 279-300.

Richards, Verlyn. D. and Laughlin Eugene J., 1980. A Cash Conversion Cycle Approach to Liquidity Analysis. Financial Management. Spring 1980, pp. 32-38.

Rybarova, D., Braunova, M., \& Jantosova, L. 2016, Analysis of the Construction Industry in the Slovak Republic by Bankruptcy Model. 3rd International Conference on New Challenges in Management and Organization: Organization and Leadership, pp. 298-306). Dubai: Procedia - Social and Behavioral Sciences, [Online] available: https://www.researchgate.net/publication/308739252_Analysis_of_the_Construc-
The Effect of the Cash Conversion Cycle on the Z-scores of Fresh Milk Companies in Greece

tion_Industry_in_the_Slovak_Republic_by_ Bankruptcy_Model/download,

Schilling, George, 1996. Working Capital's Role in Maintaining Corporate Liquidity. TMA Journal, September / October 1996, pp. 4-7.

Sen, M. and Oruc, E. 2009. Relationship between Efficiency Level of Working Capital Management and Return on Total Assets in Use, International Journal of Business and Management, 4 (10), pp. 12-17.

Shah, SM Amir, and Aisha Sana.,2005. Impact of working capital management on the pofitability of oil and gas sector of Pakistan. Editor-In-chief or e15 (3), pp. 301-307.

Sharma, A. K., and Satish Kumar.,2011. Effect of working capital management on firm profitability empirical evidence from India. Global Business Review, 12 (1), pp. 159-173.

Shin, H. and Soenen, L.,1998. Efficiency of Working Capital Management and Corporate Profitability. Financial Practice and Education, 8(2), pp. 37-44.

Shulman, J. M. and R. A. K. Cox, 1985. An Integrative Approach to Working Capital Management, Journal of Cash Management, pp 64-67.

Soenen, Luc A., 1993. Cash Conversion Cycle and Corporate Profitability. TMA Journal of Cash Management, 13(4), pp. 53-58.

Stamatelos, E. 2016, December, Strategic and Financial analysis of the Cooperative - Group of Thessaly \& Pieria Milk Producers "THESS GALA PIES", MSc thesis, Athens, Greece: Agronomic University of Athens, (in Greek), available on http://dspace.aua.gr/xmlui/bitstream/handle/10329/6583/Stamatelos_E.pdf?sequence $=3$

Stepanyan, A. 2014. Altman's Z-Score in the Airline Business. Case Study of Major U.S. Carriers. Are they Potential Bankruptcy Candidates? International Journal of Advances in Management and Economics, 3 (1), pp. 16-24, [Online] [Accessed 05 May 2018] available: http://www. managementjournal.info, 


\section{Articles}

Subramanyam, K., \& Wild, J. 2009. Financial Statement Analysis. New York: The McGraw-Hill Companies Inc, [Online] Accessed 10 November 2016, available on https://www.academia.edu/ signup?a_id=38894865,

Sugathadasa, DDK, 2018. The Relationship between Cash Conversion Cycle and Firm Profitability: Special Reference to Manufacturing Companies in Colombo Stock Exchange. IOSR Journal of Economics and Finance, 9 (6), pp 38-47. www.iosrjournals.org DOI: 10.9790/59330906023847

THESS GALA. 2018, THESS GALA Corporation official webpage, Retrieved from and available on THESS GALA (in Greek): www.thesgala.gr/ home.html,

Thomaidou, F., \& Stavraki, S. 2014. Food \& Beverage Industry: Facts \& Figures 2013. Athens: IOBE, [Accessed 17 January 2018] (in Greek) :

h t t p://iobe.gr/docs/research / RES_01_01032014_REP_GR.pdf,

Thomaidou, F., \& Stavraki, S. 2015. Food \& Beverage Industry: Facts \& Figures 2014. Athens: IOBE, [Accessed 17 January 2018] (in Greek)

h t t p : / i obe.gr/docs/research / RES_01_20032015_REP_GR.pdf,

Thomaidou, F., \& Stavraki, S. 2016. Food \& Beverage Industry: Facts \& Figures 2015. Athens: IOBE, [Accessed 17 January 2018] (in Greek) http://iobe.gr/docs/research/RES_01_7042016_ REP_GR.pdf,

Thomaidou, F., \& Stavraki, S. 2017. Food \& Beverage Industry: Facts \& Figures 2016. Athens: IOBE, [Accessed 17 January 2018] (in Greek) h t t p://iobe.gr/docs/research / RES_05_B_06042017_REP_GR.pdf,
Upadhyay, S., Sen, B. and Smith, D., 2015. The Cash Conversion Cycle and Profitability: a study of hospitals in the state of Washington. The Journal of Health Care Finance, pp 1-9.

VIVARTIA. 2018, Vivartia Official Site, Retrieved from and available on [Accessed last 05 November 2018] (in Greek) http://www.vivartia.com,

Wang, Y. 2012. Z-score Model on Financial Crisis Early-Warning of Listed Real Estate Companies in China: a Financial Engineering Perspective. System Engineering Procedia 3, pp. 153-157, [Online] [Accessed 05 May 2018] available: https://www.researchgate.net/ publication/271609947_Z-score_Model_on_Financial_Crisis_Early Warning_of_Listed_Real_ Estate_Companies_in_China_a_Financial_Engineering_Perspective/download,

Wang, Yung-Jang, 2002, "Liquidity management, operating performance, and corporate value: evidence from Japan and Taiwan." Journal of Multinational Financial Management 12 (2), pp. 159-169.

Yazdanfar, Darush and Ohman, Peter, 2014. The impact of cash conversion cycle on firm profitability. International Journal of Managerial Finance, 10 (4), pp. 442-452.

Yucel, Tulay and Kurt, Guluzar, 2002. Cash Conversion Cycle, cash Management and Profitability: An Empirical Study on the ISE traded companies. The ISE Review, 6 (22), pp. 1-15.

Zakari, Murtala Sani Saidu, 2016. The Impact of Cash Conversion Cycle on Firm Profitability: Evidence from Nigerian Listed Telecommunication Companies, Journal of Finance and Accounting, 4( 6), pp. 342-350. doi: 10.11648/j.jfa.20160406.15 